\title{
Confronting Hegemony in Mycenaean Central Greece
}

\author{
Iron that's forged the hardest \\ Snaps the quickest. \\ - SEAMUS HEANEY, THE BURIAL AT THEBES: A VERSION OF SOPHOKLES' \\ ANTIGONE
}

The central Greek mainland looms large in the cultural imagination of ancient Greece-in some ways more so than the regions sporting the better-known palatial sites of Mycenae, Tiryns, or Pylos. Only Mycenae rivals the mythological significance of Thebes, which appears to have been the preeminent palatial authority in central Greece. A second locus of Boeotian palatial power was at Orchomenos, and a third at Gla. The settlement history of Late Bronze Age Boeotia as a whole is demonstrably tied to these central places. To the north and south, Thessaly and Attica also appear to have been home to Mycenaean palaces, yet these continue to raise more questions than answers in terms of political organization, territorial scope, and even the basic composition of their archaeological remains. Of one thing we can be relatively sure, however: that these are not our canonical Mycenaean palaces, at least as understood from the type sites of the Argolid and Messenia. Nevertheless, these places appear to have been the foremost centers in the Bronze Age political landscape, and they certainly featured in later Greek imaginings of the past. Mythological resonances aside, it also seems that a good portion of central Greece had very little to do with any palace or palatial authority, which suggests that a range of sociopolitical formations were present (an observation that may be equally valid for the Peloponnese).

A fundamental problem in the archaeology of Late Bronze Age Greece is the tendency to base assumptions concerning Mycenaean polities on what we can see at Mycenae-the pomp and circumstance of elite cemeteries, monumental architecture, mysterious religious activity —and what we can read at Pylos-in Linear $\mathrm{B}$ tablets that have been used to describe the organization of territory, political 
administration, and various types of production. There is an implicit expectation, then, for palaces to look like Mycenae and behave like Pylos. Researchers have long urged us to avoid the assumption that all palaces look and act the same (e.g., Galaty and Parkinson 2007), but we seem nevertheless stuck in the proverbial rut of trying to fit lesser-known centers into frameworks to which they are often not well suited. ${ }^{1}$

This chapter examines the rise and fall of sociopolitical complexity in Mycenaean central Greece across local, regional, and interregional scales. The topic of state formation is well rehearsed for the Mycenaean world (see, e.g., Wright 2006; Parkinson and Galaty 2007; Nakassis, Parkinson, and Galaty 2011; Maran and Wright 2020). Most such studies, however, generalize the development of complexity across Greece, based especially on Peloponnesian paradigms and focused almost exclusively on palatial centers. Even studies concerned specifically with central Greece (Phialon 2011; Kramer-Hajos 2016) draw heavily on Peloponnesian comparanda, at times eliding the particularity of the region(s) in question.

This chapter begins with a discussion of nascent social complexity in central Greece. The bulk of this chapter presents a region-by-region synthesis of the political landscapes of central Greece during the Palatial period. I provide an explication of social change and organization based on the spatial analysis of settlement patterns, focusing particularly on issues of territory and regional connectivity. I argue especially that substantial variety can be seen in modes of regional sociopolitical organization, ranging from territorial palatial states to nonstate complex communities and more modest village societies.

Next, I turn to the ways in which Mycenaean polities-palaces in particularwere organized between regional and interregional scales, mainly through their interests in particular modes of production and consumption. I argue that the centralized interests (if not control) of Mycenaean palaces in various aspects of rural production represented a rapid social transformation, departing from previous ways of life, and served to set the palaces apart from other political entities. In particular, palatial interests in recording technologies (writing), large-scale agricultural projects, and the centralized production and consumption of exotica signal a desire to integrate territory and workshops in ways that had previously been much more widely distributed. We therefore see marked divergences between palatial and nonpalatial modes of social organization.

Finally, I look outward to reevaluate relationships between the Aegean and other eastern Mediterranean polities. Aegean "states" in fact do not compare well with other old-world complex societies typically ascribed that appellation. Chiefdoms or other "nonstate" sociopolitical formations may well provide better cases for comparison, though these are perhaps better characterized as a varied range of

1. Nonpalatial modes of political organization and diversity across regional systems are increasingly recognized, however, especially for the Corinthia, the Saronic Gulf, Thessaly, Achaia, and Euboea (Pullen and Tartaron 2007; Tartaron 2010; Pantou 2010; Arena 2015; Knodell, forthcoming). 
complex communities (Porter 2013). On an eastern Mediterranean stage of "great kings" and empires the Mycenaeans were probably rather poor players who have been given an outsized role, owing to the historical significance often ascribed to them (along with the Minoans) as "Europe's first states."

\section{PRELUDE: EMERGENT COMPLEXITY \\ IN CENTRAL GREECE}

Discussions of Mycenaean state formation focus on a number of related factors: burial evidence for growing social inequality, growth in the scale and number of monumental building projects, and an increase in the consumption of "elite" material culture-all in an increasingly centralized and exclusive manner. Processes begun in the Peloponnese in MH III culminate in the appearance of palace-centered states in LH IIIA2, in several parts of central Greece and the Peloponnese (see table 1; Dickinson 1977, 1994; Voutsaki 2001; Fitzsimons 2006, 18-22; Parkinson and Galaty 2007; Wright 2006, 2008). The role of Crete lingers somewhat uncomfortably in the background, ranging from influence or inspiration to adversity. Mycenaean leaders sought to establish and maintain social inequality through personal self-aggrandizement based on the exploitation of material and social networks rather than on the more integrative, distributed expressions of state authority practiced by the Minoan elite (Parkinson and Galaty 2007; see also Voutsaki 1998, 2001; Knappett and Schoep 2000). ${ }^{3}$ This took the form of (1) a monopoly on the consumption and distribution of prestige goods, such as imports and high-status craft products; (2) the control of human resources necessary for constructing monumental architecture associated with palatial authority-elite tombs and the palaces themselves; and (3) full or partial control of aspects of production (agricultural and craft) used to support the palace administration.

In transitions to statehood in early Greece the fundamental shifts concern relationships between polity and territory (the importance of land in order to produce agricultural surplus) and the institutionalization of power (the transfer of political authority from the individual to an institution-the palace). In a process of secondary state formation, increasingly complex communities of the Early Mycenaean world would have learned how to do this partly by observation, especially from their Minoan neighbors and closest contacts, but perhaps

2. These notions go back to Evans (1921) and Schliemann (1874) and have deep roots in both European and Greek notions of cultural identity, which, through the late nineteenth and twentieth centuries, became increasingly rooted in prehistory (Childe 1925; Hamilakis 2002; Papadopoulos 2005b; Hanink 2017; Voutsaki 2017).

3. A similar pattern may be observed in comparing the impact of Greek and Roman influence with the tribes of Gaul in later times (Arnold 1995). For a more minimalist, estate-based model of Mycenaean political authority based on data from Pylos, see Small 2007. 
also with influences from Ugarit and Cyprus. ${ }^{4}$ Endogenous developments played an important role as well, but the trappings of statehood-writing, administration, palatial architecture-seem to have been imported from other systems quite directly. These processes essentially describe a stimulus diffusion model, though they might benefit from more relational thinking as well. Bennet $(2017,173)$ has suggested that these relationships are better described in terms of historical links rather than typological similarities or genetic descent. At any rate, such links provided the opportunity and inspiration for the active pursuit of the stately goals of integrating territory and political authority-first in the Peloponnese and later in central Greece. In the terminology of complexity theory, we might see this as a phase transition in which new palatial institutions developed out of ones previously based on households, and aggrandizers in certain places found new ways to integrate political and economic systems, fundamentally altering the structures of early Greek society (see also Small 2019, 98).

Most reviews of the development of Mycenaean civilization leading up to the Palatial Bronze Age focus on elaboration in elite burials, particularly the development of tholoi in Messenia and the Argolid, as well as increased differentiation in the wealth of grave goods and the attendant implications for social stratification (e.g., Rutter 1993; Wright 2008). These explanations are drawn almost exclusively from Peloponnesian datasets. More recently, several scholars have sought to remedy this imbalance for central Greece (Phialon 2011; Tartaron 2013, Knodell 2013, 2017; Kramer-Hajos 2016).

Monumental tholoi in central Greece appear in only a few locations (map 9). In Attica, there are two at Thorikos (plus three further monumental tombs), one at Marathon, and one at Menidi (Acharnai). In Boeotia the only example of a tholos is the Treasury of Minyas at Orchomenos. In Thessaly there is a concentration of tholoi around the bay of Volos, with two each at Dimini (Lamiospito and Toumba) and at Volos (at Kazanaki and Kapakli). The most remote tholos is located at Georgiko. In Phokis two tholoi have been recorded in association with the site of Medeon, and another one has been found recently at Amphissa. Smaller-scale tholoi are also found in Euboea in the corridor linking the Euboean Gulf and the Aegean coasts between Aliveri and Oxylithos, at Katakalou and Velousia. The miniature tholos tombs of Thessaly are much more widely distributed-about 60 of these are known from about 30 sites-although the vast majority seem to date to the Protogeometric and Geometric periods..$^{5}$ Of the tombs listed above, only

4. On the development of secondary states, in contrast to "pristine" states, see Parkinson and Galaty 2007. On the organization of Mycenaean and Minoan palatial polities, see Shelmerdine and Palaima 1984; Voutsaki and Killen 2001; Galaty and Parkinson 2007; Shelmerdine 2006, 2008; Nakassis, Parkinson, and Galaty 2011; Killen 2015.

5. See the following works, with further references, on the tholos tombs of central Greece. For Attica, see Privitera 2013. Immerwahr $(1971,150)$ speculates that there must have been one at Athens as well, although this is purely conjectural. For Boeotia, see Aravantinos et al. 2016b on Orchomenos; a possible tholos was also found at Vouliagma in Boeotia, in a chamber tomb cemetery, although 
two seem to appear in central Greece before LH IIIA-B, at Thorikos and Kapakli (Cavanagh and Mee 1998, 44-46, 63-64). By contrast, tholos construction in the Peloponnese began as early as the end of MH III in Messenia, had spread throughout the Argolid by LH IIA. By LH IIIA-B, tholos construction became restricted to a small number of monumental tombs at major sites. At least 130 Bronze Age tholos tombs are known on the Greek mainland. Some 95 of these come from the Peloponnese, mostly from Messenia and the Argolid; of these, only about 30 have been assigned a date of construction in LH III or later (Pelon 1976; KontorliPapadopoulou 1995; Fitzsimons 2006; Banou 2008). Central Greek tholoi are therefore a rather late, secondary adoption, based on Peloponnesian influence.

Central Greek elaboration in funerary architecture can be seen in the form of funerary enclosures going as far back as the Middle Helladic period and in chamber tombs. Prominently sited enclosures, or periboloi, encircling elite cemeteries of the Middle Bronze Age and Early Mycenaean period are now known at several sites in central Greece, including Volos, Mitrou, Paralimni, Orchomenos, Eleon, Eleusis, and Vrana (at Marathon) (Spyropoulos 1971, 327-28; 1974, 322-23; Mylonas 1975; Cavanagh and Mee 1998, 29-39; Burke et al. 2020). The proliferation of wealthy chamber tomb cemeteries, especially at Thebes, Chalkis, and Athens, indicates other pathways toward social differentiation in the funerary record (Papadimitriou 2001).

Imports speak to the developing status of central Greece in wider Aegean networks. In LH II, Mycenaean palatial-type and pseudo-Minoan pottery are found at Athens, Kiafa Thiti, and Aegina, produced at both Kolonna and Athens; marine style pottery is also found at Kolonna, Athens, Thorikos, and Eleusis (Mountjoy 1999, 492; Tartaron 2013, 234). Based on the large number of imported, especially Cretan, finds at Thorikos (Laffineur 2010), it is clear that the Lavriotiki was important to Aegean traders, almost certainly as a source of copper and silver (Kayafa 1999, 311-13). The Euboean Gulf, too, may have already been seen as a route to the gold and silver sources of Macedonia. Aegina was another long-dominant player in the circulation of trade goods, with a long-distance pottery trade stretching from the Saronic Gulf to the Pagasetic Gulf in the Early Mycenaean period. At some point, Mycenae became dominant in the Saronic Gulf, while the decline of Kolonna's pottery exports was coincident with Mycenae's first verifiable palace in LH IIIA, after which Mycenaean fine wares began to appear in areas formerly under Aeginetan influence. ${ }^{6}$ The relative decline on Aegina may have opened up opportunities farther north, in central Greece, via the Euboean Gulf.

this was identified based on a thoroughly robbed-out depression in the ground (Farinetti 2011, 368). For Euboea, see Sackett et al. 1966, 73-74. For Thessaly, see Georganas 2000, 2002; Pantou 2010. For Medeon, see Livieratou 2012. For Amphissa, see Livieratou 2015, 97.

6. This picture is admittedly more complicated, however, since it also involves production sites in Attica (at Alimos), with exports of cooking vessels from Kolonna continuing throughout LH IIIB and LH IIIC (Tartaron 2013, 234-35; Gauß and Kiriatzi 2011, 245-47; Gilstrap, Day, and Kilikoglou 2016; Gauß and Knodell 2020). 


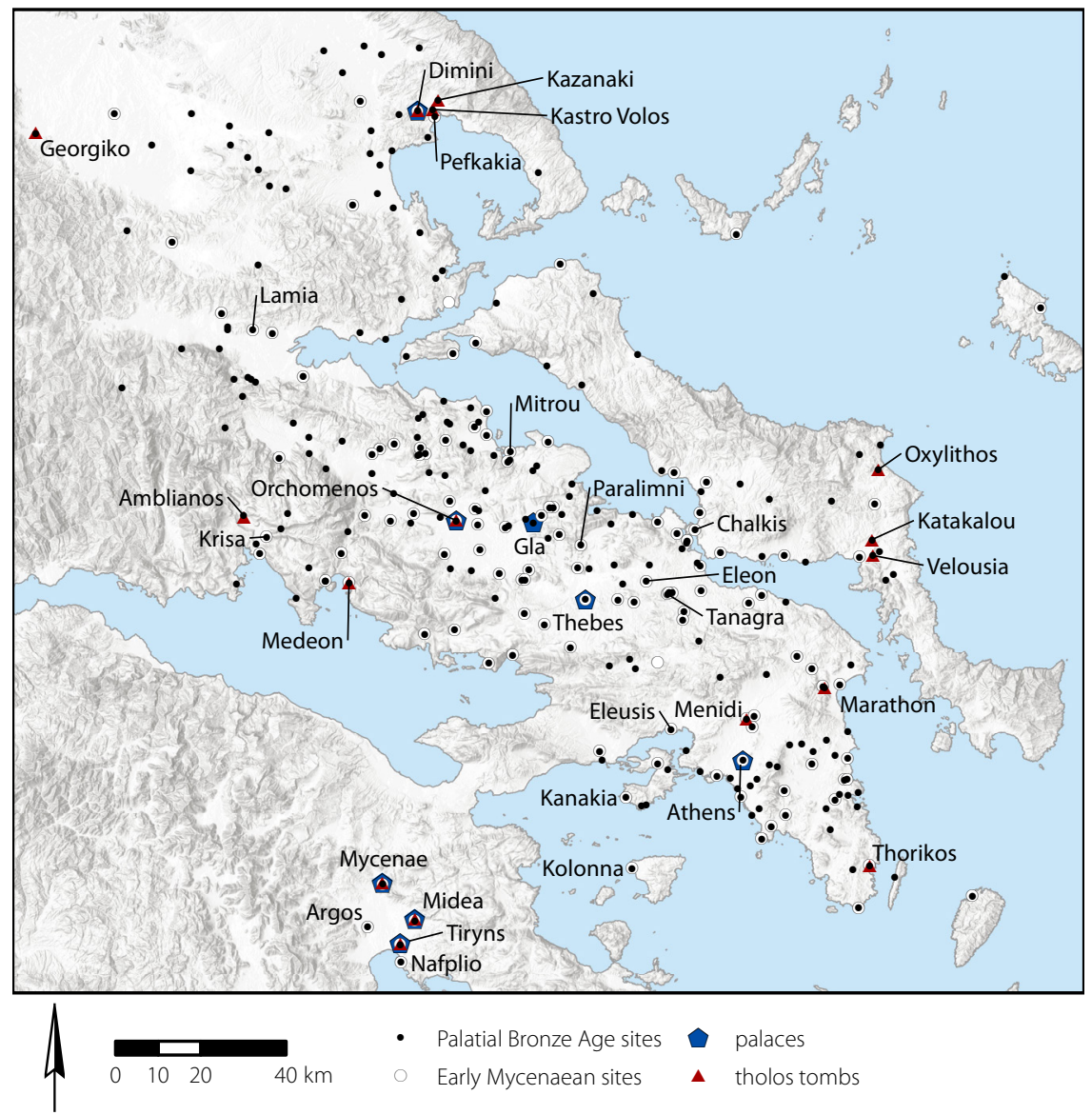

MAP 9. Early Mycenaean and Palatial Bronze Age sites in central Greece, indicating also the locations of tholos tombs and palaces (major sites in the Argolid indicated as well).

Our best evidence for state formation in central Greece is from Boeotia, namely from Thebes. The fundamental change came with the implementation of the institutionalizing framework of a palace system, which altered systems of leadership based solely on powerful individuals, as was likely the case in earlier (and later) periods, and in areas where palaces never appeared. Authority and power remained linked to individuals and households, but the office of the wanax lent greater legitimation to individual authority and allowed centralization to be perceived as occurring in the name of the state, rather than a particular person. ${ }^{7}$ Moreover, the

7. On the sociopolitical role of the wanax (wa-na-ka in Linear B), see Palaima 1995, 2006; Nakassis 2012. There is little doubt that the wanax is the central figure in the Mycenaean sociopolitical hierarchy (Shelmerdine 2006), having a capacity to command comparable to other versions of kingship in early complex societies (Wright 1995). The etymology of the term is somewhat opaque, though its meaning 


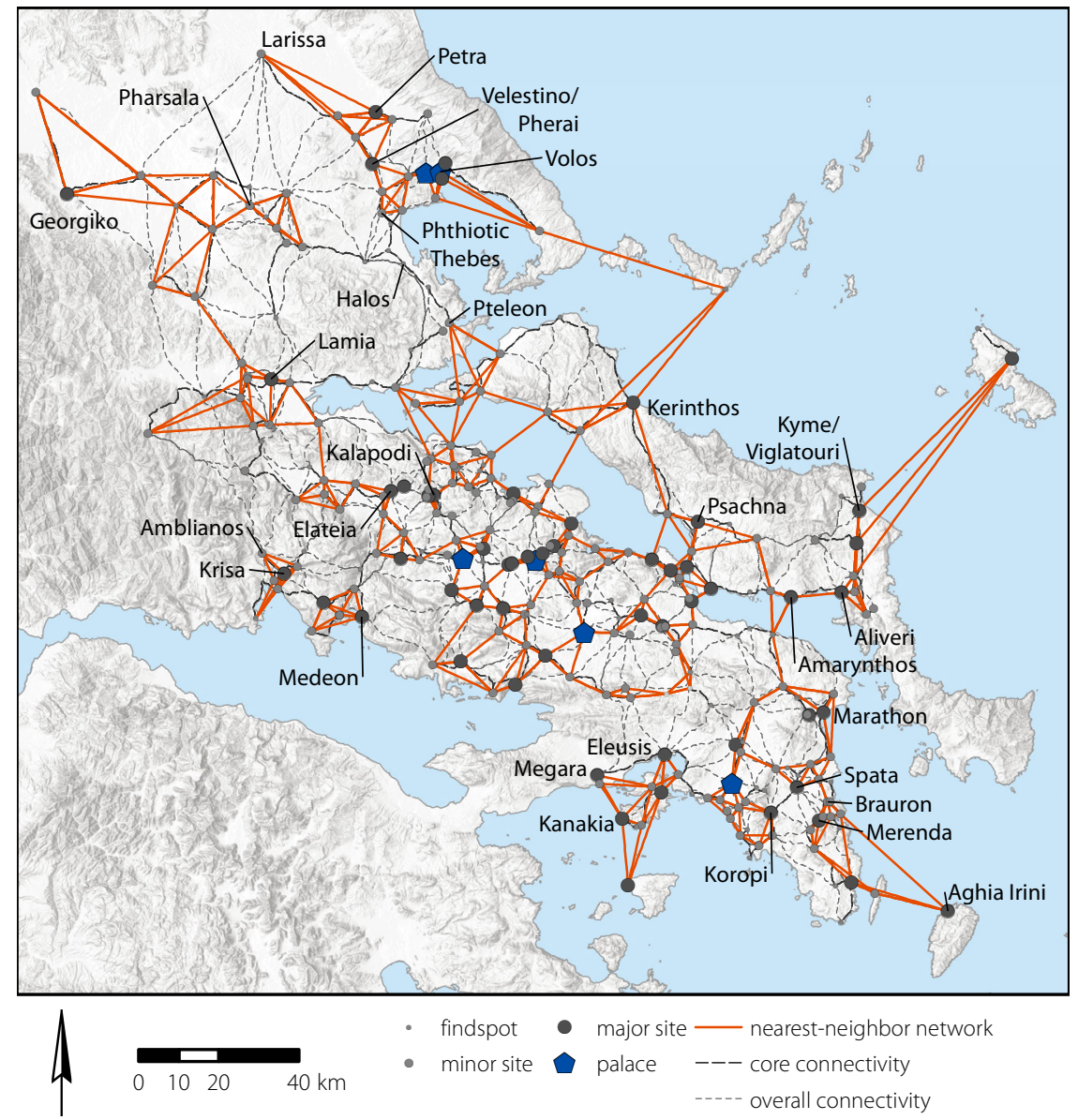

MAP 10. Palatial Bronze Age sites, joined by a connectivity model, with a nearest-neighbor network of communities (see also maps 9, 12, and appendix for additional place names).

control of agricultural resources-land-was expanded and systematized in new ways, eventually involving detailed record-keeping.

There was a strong Cretan connection at Thebes, evidenced by some 70 fragments of inscribed stirrup jars, nearly all of which are thought to come from

may be related to the Hittite word hassu- (king), which has to do with birth, fertility, and lineage-that is, the basis for kingship is linkage to ancestral (and divine) power and the capacity to produce for his people (Palaima 2006, 57). It is also noteworthy that the wanax and the second-in-command lawagetas ( $r a-w a-k e-t a)$ were the only individuals to possess a temenos (te-me-no), which is often interpreted as meaning landed estate but is clearly related to the later Greek word for sacred space (Palaima 2006, 62; Nikoloudis 2008b, 590). This linkage has implications for a relationship between kingship and religious authority, or at least suggests that the spaces inhabited by these individuals were important places of group religious practice. 
western Crete, probably from a Mycenaean palace at Kydonia (modern Chania) (Haskell et al. 2011). Moreover, larnax burials from Tanagra dating to LH IIIA and $\mathrm{B}$ and the earliest frescoes from Thebes both show formal and stylistic similarities to contemporary and earlier forms in Crete (Brysbaert 2008a, 2008b). This Minoan interface was crucial elsewhere-especially in the Peloponnese-for the development of Mycenaean sociopolitical complexity.

We cannot demonstrate that there was as strong a Minoan connection in central Greece as there was in the south, but some general patterns are nevertheless apparent. First, the areas with early tholos tombs are mainly coastal and represent important access points to resources and routes: in the case of Thorikos, the obvious attractions are the resources of the Lavriotiki and the access to the Euboean Gulf; in Volos, there are the agricultural riches of Thessaly, along with land routes northward. These form anchor points on either end of the Euboean Gulf, where local elites profited from and were influenced by long-standing, long-distance contacts. The Lavriotiki was the source for much of the silver in the Aegean datable to this period, while the shaft graves at Mycenae also exhibit connections to silver sources in northern Greece (Stos-Gale and Gale 1982; Stos-Gale and Macdonald 1991, 273-79; Papadopoulos 1996b, 173; 2005, 588-91). The Euboean Gulf, then, provided a maritime axis along which interregional connections engendered transitions in complexity between the Early Mycenaean and Palatial periods.

In sum, the growth of Thebes, Orchomenos, Volos, and Athens suggests the centralization of political authority, which can be seen as a type of secondary state formation, corresponded with expanding regional networks and changing attitudes toward land, territory, and leadership. Each of these centers had the potential to command major agricultural resources in a way not shared by other significant Mycenaean sites. The control of land was a particularly important means of consolidating power. Agricultural expansion and surplus also created opportunities for specialization, as we see in episodes of state formation across the globe. Coastal areas were not in such a good position to intensify agricultural production, at least not on the same scale, and they may not have faced the same pressures to do so with easier access to the sea. The influx of imports in the Palatial period also suggests an expansion of interregional networks. This rapid intensification of interactions on multiple scales, then, can explain the apparent speed with which the palaces emerged in central Greece as a major transition in social organization.

\section{THE POLITICAL LANDSCAPES OF MYCENAEAN CENTRAL GREECE}

The Palatial period coincides with a major boom in the number of settlements across the Greek mainland. In the first place, the number of Palatial versus Early 
Mycenaean sites more than doubles, going from 114 to 276 (see map 9, table 4). ${ }^{8}$ There are a few possible ways to explain this boom and its relationship to social change. Population increase could have led to more settlements and competition over territory, out of which leaders emerged to form administrative structures that had been adopted from other states. Alternatively, changing administrative structures could have led to the formation of new, more productive agricultural strategies and population growth as a result of state protection and without the threat of raiding from neighbors. Or there could be a question of archaeological visibility, with Palatial Mycenaean pottery being more prevalent and diagnostic than that of earlier periods; therefore, sites are much more recognizable as belonging to this period. A complexity perspective would suggest that the properties described in the first two scenarios-population growth, increasing social complexity, intensification of production-emerged together, in mutual dependence. The visibility issue probably applies as well, but it is difficult to accept as a sole explanation given the scale of change and number of well investigated sites that do not have Early Mycenaean remains.

A combined map of the settlement hierarchy and connections between communities shows clear clusters forming (map 10). While there is sometimes a pattern of second order sites relating clearly to palatial sites (as in Boeotia), most clusters in the model have no demonstrable relationship to palaces (e.g., in Phokis, Malis, Thessaly, Euboea, and the Saronic Gulf).

As for the palaces themselves, there are only six sites in all of central Greece that can be considered palatial in character, and there is a wide amount of variability between them. Boeotia offers the most straightforward cases, with palatial centers at Thebes, Orchomenos, and Gla. Athens seems also to have been home to a palace, although later building on the Acropolis has obliterated much of the evidence for it, so our understanding is sketchy at best. Thessaly offers another curious case with the palatial character of at least two sites, Dimini and Kastro Volos. The latter is subject to the same problems as Athens but has some Linear B tablets. Kanakia, on Salamis, is sometimes described as a palace as well, though this is less likely.

The architectural remains at these sites have some attributes in common. In relative terms they are simply much larger than other sites and building complexes in their respective regions. There is evidence for elite burials in the form of wealthy cemeteries, of a hierarchy of space indicated by defensive walls and restricted access to central buildings, and of preferential consumption of "elite" aspects of material culture at an institutional level-wall paintings, monumental architecture, painted pottery, feasting equipment, and exotica. Evidence for sponsored activities like feasting and administrative action is also apparent.

8. Some sites are designated simply "Mycenaean," based on ambiguous information in reports or databases meaning they could either be Early Mycenaean or Palatial. See appendix for the period designations of individual sites. 


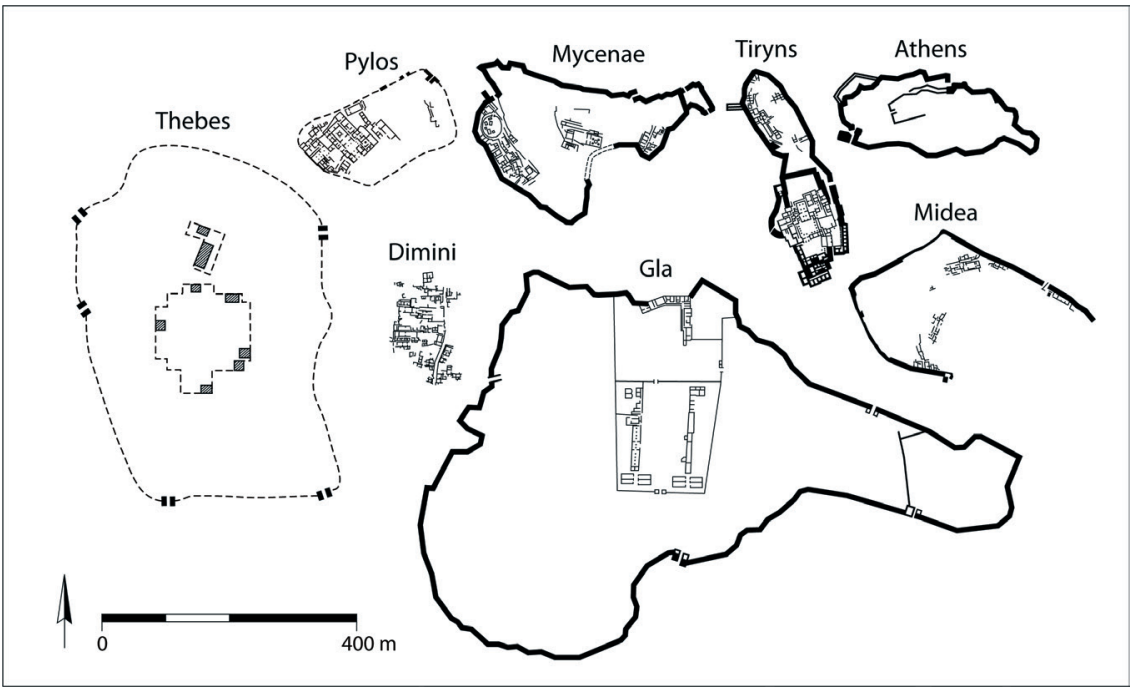

FIGURE 3. Comparative sizes of Mycenaean palaces, showing the form and extent of architectural remains where known and putative extents as dotted lines-that is, the putative extent of the citadel and palatial area at Thebes, which is largely obscured by the modern city (illustration by Denitsa Nenova, after Blegen and Lang 1961, fig. 1; Symeonoglou 1985, 33; Hope Simpson and Hagel 2006, fig. 2; Adrimi-Sismani 2007, 162).

All these characteristics are shared with palatial sites in the Peloponnese. But on closer scrutiny the palatial buildings of central Greece bear little resemblance to their southern counterparts. For one thing, we simply know much less about their architectural layout. While the central palatial buildings of Mycenae, Tiryns, and Pylos have all been excavated extensively, the same cannot be said for any of the palatial complexes of central Greece. Thebes, Orchomenos, and Kastro Volos are mostly buried by millennia of subsequent occupation and remain at the centers of modern towns. Palatial materials on the Acropolis of Athens are fragmentary, mostly obliterated by later constructions. Only Gla and Dimini are reasonably accessible, though the history of excavation at these sites pales in comparison to the Peloponnesian centers (Iakovidis 1989, 1998, 2001; Adrimi-Sismani 2017, 2018).

One thing we do know about the architecture is that there is a tremendous amount of variation in size (figure 3; see also Whitelaw 2017). Thebes and Gla are far larger than anything else in the Mycenaean world, their circuits (estimated in the case of Thebes) being several times larger than Mycenae, even at its greatest extent. None of the central Greek palaces has an obvious central megaron, a hallmark of palatial arrangements in the Peloponnese. On the contrary, Gla and Dimini both have double megaron structures that are often considered anomalous (see, e.g., Iakovidis 2001; Adrimi-Sismani 2018). No such structure has been found at Thebes or Orchomenos, and the closest proxy in Athens is a column base thought to come from a palace (Iakovidis 2006). 
Taking a step back from the palaces themselves, we may ask the question: what did palatial territories and political organization look like? A fundamental shift in the relationship between land and polity and rulers and subjects happened in the Mycenaean Palatial period, when states aimed to centralize significant aspects of the subsistence-based agricultural systems that had been the norm in rural communities for the previous several millennia. This is clear in the siting of palatial sites in large agricultural plains, with immediate access to land capable of producing a significant surplus through intense cultivation.

The palaces also provide the only textual evidence we have for understanding the organization of society in the prehistoric Aegean. We do not have a good understanding of how agrarian systems looked before or after the palaces owing to the absence of documentary sources, but this very lack of administrative apparatus also means that the complex hierarchies present in the palaces could not have been maintained in the same way before or after. Such territories previously would have been under the control of powerful families and households, and they would have been much more fragmented. Palatial practices of centralization, fortification, and resource accumulation brought their products under one political roof.

Most of what we know about these territorial systems comes from the study of Linear B tablets-specifically, the two largest corpora from Pylos and Knossos. ${ }^{9}$ While the Pylian system cannot be projected wholesale onto other Mycenaean palaces, it nevertheless provides the most complete example. ${ }^{10}$ Territorial organization is best revealed through the administrative offices recorded in the tablets, which at Pylos demarcate three levels of territorial hierarchy: (1) the polity as a whole, controlled by the palace and its personnel-the wanax and his second in command, the lawagetas, and certain enforcers and administrators working directly for the palatial authority; (2) the regional units, or provinces, into which the polity was divided, which had administrative overseers; and (3) the local district, or damos, which seems to have had both administrators connected directly to the palatial system and local leadership institutions that appear to have existed before the advent of palatial administration-for example, the basileus or

9. Aravantinos $(2010,58)$ gives the following numbers for Linear B texts. Knossos: ca. 3,500 texts and many fragments; Pylos: ca. 1,200 texts and many fragments; Thebes: ca. 350 texts on tablets, 70 inscribed stirrup jars, many fragments, plus ca. 250 new texts from the Pelopidou street excavations; Mycenae: 70 or more texts and some fragments; Tiryns: 25 texts on tablets and a few on stirrup jars; Midea: 4 inscribed sealings; Dimini: 2 texts, a stone object and an inscribed pottery sherd; Aghios Vasileios: 3 fragmentary tablets; Chania: 4 fragmentary texts on tablets and several inscribed stirrup jars.

10. The Knossos tablets also shed light on territorial and administrative organization, and indeed may be significantly earlier than the Pylos tablets; however, the Pylos archive provides the most detailed snapshot from a particular time and place-around 1200 BCE (Bennet 2011, 2017; Godart and Sacconi 2020; Nakassis, Pluta, and Hruby 2021). Nakassis (personal communication) notes that the organization of Thebes resembles Knossos more closely than Pylos, based on the limited evidence available. This may suggest that Pylos was the anomaly, or that administrative systems developed in slightly different ways out of a common ancestor at Knossos. 

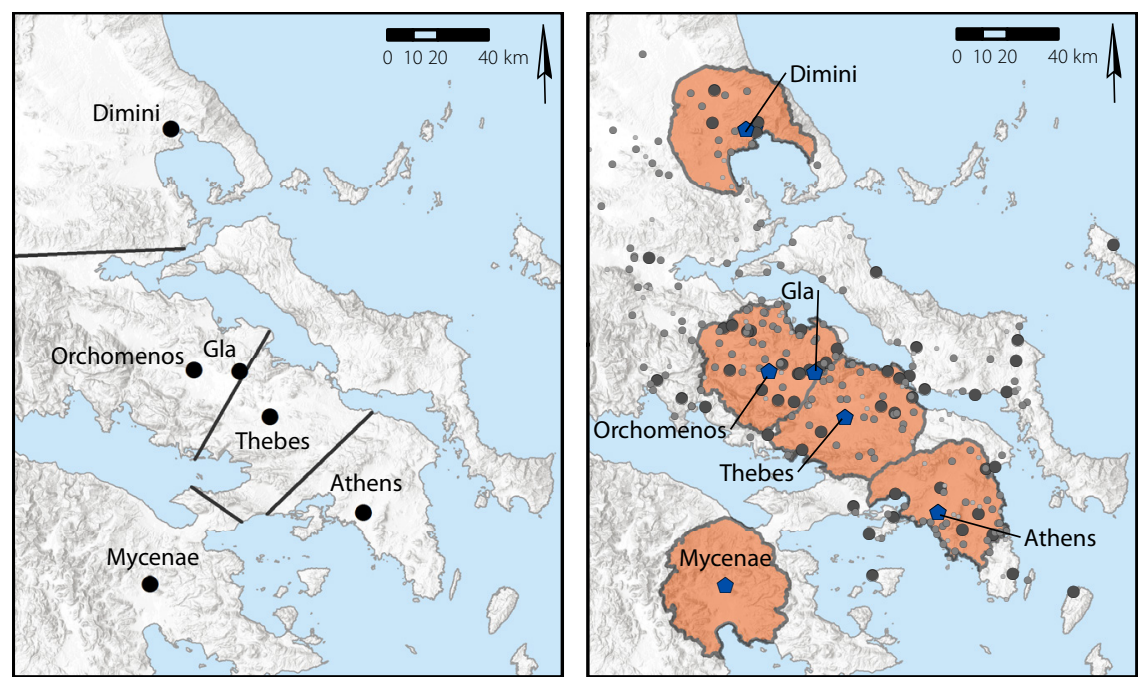

MAP 11. Comparative territories for Mycenaean palaces using Thiessen polygons (left) and a limited cost allocation method (right, showing also the settlement hierarchy for the Palatial Bronze Age).

chief and a single priest or priestess (Morpurgo-Davies 1979; Nakassis 2013a, 5-14). The terms for these latter two institutions both continue after the collapse of the palaces, along with wanax (as a less specific term for leader), while other terms do not, suggesting that the other terms were specific to this palatial system. The extent to which such a system applied to other palaces is subject to debate, but the evidence from Knossos and Thebes suggests similar general offices and structures: administrative offices at three levels; the division of space into subregional units; and some (but not all) communities that coincide with later place names.

Finally - and significantly - there is a large amount of settlement activity in the landscape that is quite far removed from any palatial center, in both spatial and network terms. Based on what we know of the remit of Mycenaean palaces, it seems highly unlikely that these other regions fell under any form of palatial control, although they could and probably would have been part of the same wider interaction spheres and cultural milieu.

The territorial and network models described in chapter 2 (pp. 56-60) offer new insights into regional connectivity, territoriality, and landscape diversity in central Greece during the Palatial period. A model of palatial territory based on Linear B texts in Boeotia, for example, can be applied to other palatial regions as a heuristic device (map 11). We can also use such a model to suggest which areas are better defined as simply "nonpalatial"- that is, outside the likely territorial remit of any known palace (see also Knodell, forthcoming). From there we can begin to reconstruct the political landscapes of central Greece on a region-by-region basis. 
Some comparison between these modeled territories provides a convenient starting point. Most Mycenaean palaces are located somewhat inland, all at locations well positioned to control vast swaths of agricultural land. Access to the sea was also important, given the cultural significance of exotica, the dependence on bronze trade, and the more general participation in long-distance networks (see further below). Modeled territories are roughly similar in size; they are between 1,500 and 2,000 square kilometers, and so in general are larger than Renfrew's (1975, 14) estimate of 1,500 square kilometers in his Early State Module, even though these are all smaller than the territorial allocations that would result from Thiessen polygons. Estimates of Pylian territory based on various studies of Linear B documents also project a territory of about 2,00o square kilometers (Bennet 1995, 587; Whitelaw 2001, 64; Nakassis 2013, 236; see also Hope Simpson 2014). Notable clusters of sites occur within modeled territories; in the cases of Attica and Thessaly the resulting networks are distinct from areas outside of the territory. Clusters are also apparent around major sites outside the palatial territories-for example, in central Euboea, the island of Salamis, western Phokis, Doris, and Thessaly. In terms of site hierarchy, there is a significantly higher percentage of major sites within palatial areas, suggesting centralized investment or interest in sites within a particular territory, although larger-scale sites are also found outside areas that fall within the modeled remits of known palaces. Taken together, these patterns suggest a range of sociopolitical complexity in the networks of communities that can be identified throughout central Greece.

\section{Contest and Confrontation in the Plains of Boeotia}

Boeotia boasts a long tradition of archaeological research, especially in terms of regional survey (see table 3 ). This factor may contribute to the high number of known sites in the region, although the number of secondary and tertiary sites (with more obvious, long-known remains) is also quite high, suggesting that the large number of sites is not simply attributable to the history of research. In addition to the archaeological record of settlement, we also have textual attestations of the political landscape in the form of Linear B documents from Thebes (Chadwick 1970; Spyropoulos and Chadwick 1975; Olivier, Melena, and Piteros 1990; Aravantinos, Godart, and Sacconi 2001, 2002; Deger-Jalkotzy and Panagl 2006; Del Freo 2009; Palaima 2011).

Linear B tablets, nodules, and inscribed stirrup jars from Thebes (the latter found in other locations as well) offer evidence for conceptions of territory in the Mycenaean world in the form of toponyms, ethnics, and ethnic anthroponyms, though their meanings are often ambiguous (Del Freo 2009; Haskell et al. 2011) (table 7). As economic administrative documents, Linear B tablets record quantities of items going to or coming from particular locations. Sometimes place names are recognizable owing to their appearance in later periods, but there are only rarely clear indications of territorial control (contra Aravantinos, Godart, 
TABLE 7 Connections with Thebes based on Linear B documents (see also map 12)

\begin{tabular}{|c|c|c|}
\hline Linear B & Location & Interpretation \\
\hline te-qa & Thebes & Palace \\
\hline$e-r e-o-n i$ & Eleon (modern Arma) & Second-order center \\
\hline$e-u-t e-r e-u$ & Eutresis & Second-order center \\
\hline$k u$-te-we-so & $\begin{array}{l}\text { Unknown-likely } \\
\text { close to Thebes? }\end{array}$ & $\begin{array}{l}\text { Second-order center; suggested that it is close to } \\
\text { Thebes based on location of other second order } \\
\text { centers }\end{array}$ \\
\hline$k e-r e-u$-so & Kreusis & $\begin{array}{l}\text { Port site on the Corinthian Gulf; possible } \\
\text { second-order center; also possibly a personal name }\end{array}$ \\
\hline$a_{3}-k i-a_{2}-r i-j a$ & $\begin{array}{l}\text { Unknown-likely a } \\
\text { coastal site on the } \\
\text { Euboean Gulf }\end{array}$ & $\begin{array}{l}\text { Related to later Greek term used to refer to sandy } \\
\text { shores; perhaps Glypha/Aulis? }\end{array}$ \\
\hline po-ti-ni-ja wo-ko & $\begin{array}{l}\text { Potniai (modern } \\
\text { Tachi) }\end{array}$ & House/shrine of the potnia; unit of wool sent here \\
\hline po-to- $a_{2}-j a$ & Mount Ptoon & Group of men sent here \\
\hline ra-mo & $\begin{array}{l}\text { River "Lamos" flowing } \\
\text { from Helikon (modern } \\
\text { Archontitsa) }\end{array}$ & Unknown quantity of wool sent here \\
\hline$a-m a-r u-t o$ & Amarynthos & $\begin{array}{l}\text { One pig sent to Thebes (nodule Wu 58); shipment of } \\
\text { wool to Amarynthos (tablet Of 25) }\end{array}$ \\
\hline ka-ru-to & Karystos (?) & One pig sent to Thebes (nodule Wu 55) \\
\hline [? ki-ta-]ro-na & Kithairon (?) & Something toward Mount Kithairon \\
\hline wa-to & Western Crete & $\begin{array}{l}\text { On inscribed stirrup jar; attested in Knossos tablets } \\
\text { as near Chania }\end{array}$ \\
\hline$o-d u-r u-w i-j o$ & Western Crete & $\begin{array}{l}\text { On inscribed stirrup jar; attested in Knossos tablets } \\
\text { as near Chania }\end{array}$ \\
\hline $\begin{array}{l}i-s i-w i-j o-i \\
\text { (anthroponym) }\end{array}$ & $\begin{array}{l}\text { Isos (Pyrgos, near } \\
\text { Anthedon) }\end{array}$ & Men from Isos as recipients of wine \\
\hline $\begin{array}{l}m i-r a-t i-j o \\
\text { (anthroponym) }\end{array}$ & Miletos & Several tablets record allotments of barley \\
\hline $\begin{array}{l}\text { ra-ke-da-mi-ni-jo } \\
\text { (anthroponym) }\end{array}$ & Lakedaimon & $\begin{array}{l}\text { Records quantities of wheat coming in (?) and wine } \\
\text { being sent there }\end{array}$ \\
\hline
\end{tabular}

and Sacconi 2001, 2002; Bennet 2017). For example, the names Amarynthos and Karystos, both of which are towns in Euboea, appear in the Linear B tablets from Thebes as a-ma-ru-to and ka-ru-to (Piteros, Olivier, and Melena 1990, 153-54; Del Freo 2009, 42, 47; Palaima 2011). Yet there is nothing that specifies a tributary relationship between the palace and these places on Euboea-they are listed only in the context of goods going to or coming from them. One pig is delivered from $a$-ma-ru-to to Thebes and some allotments of wool go to a-ma-ru-to from Thebes, while one pig is delivered to Thebes from $k a-r u$-to. The former seems to be a 


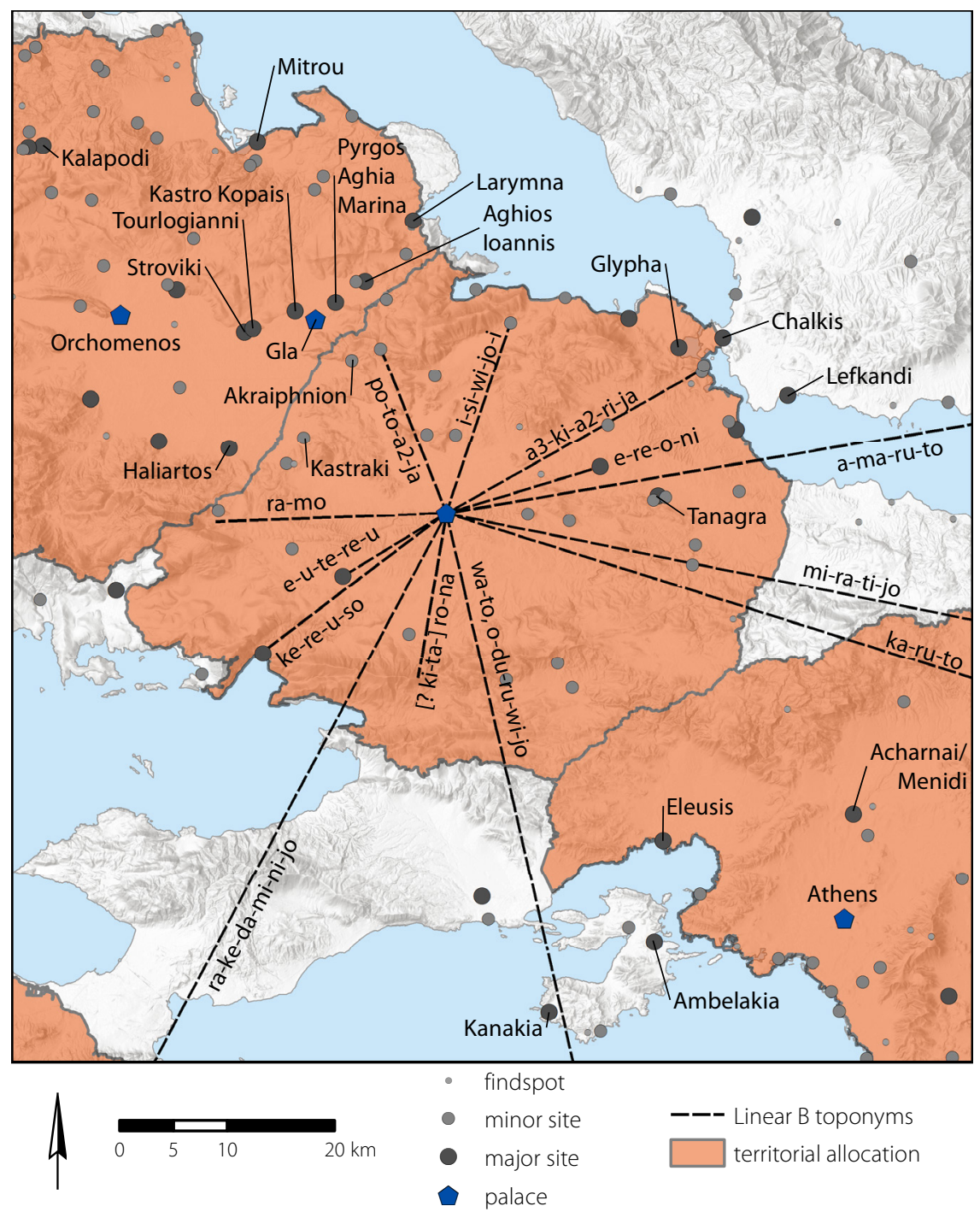

MAP 12. Network of sites mentioned in the Linear B tablets from Thebes and the modeled extent of Theban territory, with settlement hierarchy and significant sites indicated (see also table 7).

simple exchange and the latter hardly suggests some kind of hegemony. Following Palaima (2011), I would disagree with arguments that make Euboea part of the territory of Thebes (Aravantinos, Godart, and Sacconi 2002; Del Freo 2009, 66; see also Knodell, forthcoming).

The Linear B tablets from Thebes provide more information about the political geography of Boeotia. First, there is no question that Thebes is the dominant 
political center in at least its immediate area, which encompasses the Theban plain. This is the only site in central Greece at which a significant number of Linear B texts have been found, and the record keeping evidenced there is in line with other Mycenaean central authorities, revealing agricultural and other goods coming into and going out of the palace. Linear B documents have been found at no fewer than six separate locations in Thebes (Aravantinos 2015, 36); this suggests a somewhat more widely distributed set of administrative activities than, say, at Pylos (the only site where a proper archive room has been found). LH III Thebes is also by far the largest site in the region, with an enceinte comparable to that at Gla, which dwarfs the Mycenaean centers of the Peloponnese (see figure 3; see also Symeonoglou 1973, 1985, 31-32; Aravantinos 2010).

Del Freo (2009) argues that only four of the 25 toponyms in the Thebes tablets can be associated with a clear political hierarchy. The first is Thebes itself: te-qa. Three other sites appear as sort of second-order centers, which is argued based on the described size of their crops: e-re-o-ni (classical Eleon, near modern Arma), $e-u$-te-re-u (ancient Eutresis, now called Arkopodi), and $k u$-te-we-so, the location of which is unknown but probably close to Thebes. ${ }^{11}$ Other sites that are mentioned do not seem to be involved in administrative activities. From this Del Freo $(2009,67)$ argues for a three-tier settlement hierarchy, similar to Pylos-which also has two second-order centers-and Knossos (Bennet 1985, 1995). By contrast, the Linear B tablets of Pylos record some 240 toponyms (Bennet 1995, 594; Nakassis 2013a), while those at Knossos record about 100 (Bennet 1985, 233). The Thebes records, however, come from only piecemeal excavations of the site, whereas Pylos and Knossos were excavated much more comprehensively.

Based on the texts that are known and the archaeological sites to which they can be related, Del Freo (2009, 66-67) proposes a territorial division between Orchomenos and Thebes, which is attested in later periods (see also Dakouri-Hild 2010a). This fits quite well with a spatial model of Theban territory, in which all the sites with recorded economic relationships to Thebes seem to fall into territory close to Thebes, or to the south or east (map 12).

Beyond the secondary centers of Eleon and Eutresis, two other major sites within the Theban polity are located along the projected border with Orchomenos: Potniai and Ptoon. Other major sites are located at the main access points to the sea. There is a fortified site in the protected bay of Livadostro/Kreusis (appearing in the Thebes tablets as ke-re-u-so) on the Corinthian Gulf, and there are three important sites on the Euboean Gulf near the Euripos, all of which are positioned at prominent topographical locations and seem to have been fortified. Drosia/ Lithosoros is located in a small, sheltered bay on the north side of the Euripos.

11. Eleon has been the subject of recent excavations by the Eastern Boeotia Archaeological Project, which also conducted three seasons of intensive survey in the area. See Aravantinos et al. 2016a; Burke et al. 2020. On Eutresis, see Goldman 1931; Mountjoy 1983, 93-95; Farinetti 2011, 342; Van Damme 2017b, 96-99. 
Glypha is across the Euripos from Chalkis. Dramesi/Paralia Avlidos is just to the south. Aulis, which also has Mycenaean remains, is located in between the latter two (Ghilardi et al. 2013). Together, these would have formed a set of strategic access points to the sea, surrounding an important choke point (the Euripos) that could only be passed at certain times of the day. In the southwest, Plataia was located near the Kaza Pass on the Boeotian side of Mount Kithairon (another liminal area mentioned in the Thebes tablets), which was the main route of access to Attica and the Peloponnese via the Mazi Plain. This area was apparently already a crossroads in Mycenaean times (Knodell, Fachard, and Papangeli 2017, 160; Fachard and Knodell 2020). In the southeast, Tanagra was sited over an important agricultural valley along another main route of access to the Theban Plain. Significantly, there are no locations mentioned in the Thebes tablets that fall within the modeled territory of Orchomenos. ${ }^{12}$

A final group of geographical referents is made up of anthroponyms: two are Cretan, three are Anatolian, and one is Laconian. The occurrence of such anthroponyms is not unusual, and these personal names do not necessarily mean a person was from the place in question; they do, however, illustrate some aspects of the wider world of which Thebes was a part. With the possible exception of Troy and Sminthos, the only other sites mentioned have significant Mycenaean components (see table 7). So, while the Linear B texts provide locations and goods coming or going, a geographical reading indicates that Thebes is mostly concerned with its significance as a regional power in Boeotia, with occasional indications of places and people farther afield. There is nothing in the Linear B texts about diplomatic relationships or long-distance trade (Murray 2017, 32-34).

The territorial models resulting from an analysis of the Thebes tablets provide a convenient starting point for understanding the extent and operations of other Mycenaean palaces, even if we should be cautious about considering such analogies absolute. While we have more to say about the specifics of the Theban case, the same factors may be kept in mind when considering the political landscapes of other palatial entities, most notably Orchomenos, from an archaeological perspective.

Orchomenos was a developing center in the Early Mycenaean period (and an important $\mathrm{MH}$ center well before), with cemetery remains spanning MH III-LH IIIA (Sarri 2010). Prehistoric material has been reported on the lower slopes of the Classical acropolis but this has only been scantily published (Schliemann 1881; de Ridder 1895; Bulle 1907). Most Mycenaean material comes from below-in the vicinity of the modern town and monastery of Panaghia Skripou. Orchomenos boasts several vestiges of a Mycenaean palace, including wall paintings, "palatial"

12. It has been occasionally suggested that $a$-re-o may represent Halai, which appears to be on the other side of Orchomenian territory. This appears to be a personal name, so it does not indicate a particular place; nor does it imply some sort of territorial relationship, even if it is an ethnic (KramerHajos 2006). 
buildings, and the only tholos tomb in Boeotia-the so-called Treasury of Minyas-which Pausanias (Description of Greece 9.36.4-5) compared to the walls of Tiryns and the pyramids of Egypt in its magnificence (Alcock and Cherry 2006; Aravantinos et al. 2016b). Near the monastery, Spyropoulos (1974) found architectural remains and fresco fragments, including scenes of an organized military and an armada. ${ }^{13}$ This subject matter, together with the substantial buildings, the elite cemeteries, and the literary tradition, suggests that there was a palatial authority present, comparable to other Mycenaean centers.

The wider pattern of settlement for northwestern Boeotia is not as clear-cut as for Thebes. The cost-based territorial model employed here would put the northern boundary of Orchomenian territory well into East Lokris. We might also suggest a more modest territorial extent, bounded in the north by the natural geographical barrier of Mount Chlomon. This would imply a territory extending to the west and northwest of Orchomenos to Chaironeia and Panopeus; indeed, it seems likely that Orchomenian interests would have extended south to the outlet of the Corinthian Gulf at Medeon and Antikyra (see further below, on southern Phokis). To the north, the territory of Orchomenos may have extended farther up the Kephisos valley as far as Elateia and Kalapodi, although the latter would have involved entering the geographically distinct valley between Kallidromon and Chlomon. Eder (2007, 90-98) has demonstrated links between Medeon and Elateia (among other parts of the Mycenaean world) in the form of identical seals and sealings, which she associates with Orchomenos. Van de Moortel and colleagues (2019) have suggested that the expanding polity of Orchomenos may have been responsible for a widespread LH IIIA2 destruction at Mitrou. It seems, then, that the northern extents of Orchomenian territory were likely dynamic and contested. The most important territorial extent of Orchomenos was to the east, where a network of sites stretches to Larymna as a point of access to the Euboean Gulf and establishes a border with Thebes to protect this and the Kopaic Basin.

The drainage of Lake Kopais and construction of the fortifications at Gla represent a building and engineering effort greater than anything known in the Mycenaean world at the time. The drainage alone diverted four rivers through the construction of polders, embankments, and canals, many of which had cyclopean revetments. Building the dykes on either side of the canals involved moving an estimated 2 million cubic meters of earth and 250,000 cubic meters of stone. The total amount of land reclaimed was approximately 1,500 hectares (Knauss, Heinrich, and Kalcyk 1984; Knauss 1987; Iakovidis 2001; Kountouri et al. 2012; Lane et al. 2016, 2020). Recent work by the AROURA and MYNEKO projects has suggested that the drainage works in the Kopais are 300 to 400 years older than the fortification works at Gla, which are traditionally dated to LH IIIB1 (Lane et al. 2016). This date is surprisingly early and should be approached with some caution. This type and this scale of land amelioration is nearly impossible to imagine

13. These wall paintings can be viewed in the Thebes museum. See Tournavitou 2017 for comparable scenes from the West House at Mycenae. 
without the aegis of some form of state-level authority, of which there is no other evidence in the Early Mycenaean period. Comparative research on complex societies in Mesoamerica has demonstrated that such large-scale systems of dykes and canals require massive collective action, are rare, and, when they do occur, appear well after the rise of hierarchical polities; smaller-scale networks of canals and dams, by contrast, can emerge much earlier (Carballo, Roscoe, and Feinman 2014, 116-17). It may be the case, therefore, that small-scale canal networks were created during the Early Mycenaean period but expanded substantially in Palatial times.

A regional program of fortification was undertaken in LH IIIB, with new sites or forts established at Pyrgos, Stroviki, Kastro Kopais, Aghia Marina Pyrgos, Aghios Ioannis, and Larymna (see map 12). Haliartos, on the southern border, was fortified as well. I argue that the purpose of this fortification system was threefold: (1) to protect the agricultural investment in the Kopaic Basin; (2) to secure the route between Orchomenos, Gla, and the Euboean Gulf; and (3) to monitor the nearby border with Thebes.

Gla was at the center of this program of agricultural innovation and fortification. The earliest pottery at Gla can be dated to LH IIIA2/B1. LH IIIA2 forms have parallels in LH IIIB1 and in any case are found in contexts dominated by LH IIIB1 forms. Iakovidis $(2001,142-45)$ thus dates the construction to the LH IIIB1 period, or around 1300 BCE. Occupation lasted until the citadel's destruction in LH IIIB2, shortly before 1200 BCE (Iakovidis 2001, 145). Gla has the largest complete circuit of any Mycenaean site, as well as numerous interior buildings. ${ }^{14}$

Gla has traditionally been interpreted as a military or agricultural redistributive center (Iakovidis 2001). Kramer-Hajos (2016, 115-25) has recently argued that the construction of Gla was a joint venture between Orchomenos and Thebes, noting that the wider system of fortifications was to the north of the Kopais rather than being oriented toward Thebes. This is true, but it does not account for the geographical division between the two territories. Moreover, there are significant fortified sites at entry points on the "Theban" side at Kastraki and Akraiphnion, and on the "Orchomenian" side near Haliartos. The northern fortifications were intended to protect and monitor this northern extent of territory, to be sure, but also to secure the important land route between Orchomenos, Gla, and the port of Larymna. The connection between these places in the landscape-all falling within a panoramic view from Orchomenos-lends further credence to an association specifically with this site and not with Thebes.

Contrary to arguments that Gla was an agricultural facility or some kind of joint venture, I suggest that Gla was built as a relocation of Orchomenian palatial authority in the center of a new agricultural and defense network (see also Knodell 2013, 165-66; forthcoming; Maggidis 2020). The palatial characteristics of the site itself are several. The monumental circuit wall is far larger than that of any other

14. Recent site clearance and geophysical survey at Gla have revealed that building remains were much more extensive than previously thought (Maggidis 2020, 114-15). A new program of survey and excavation, directed by Kountouri, is currently underway (2018-22). 
Mycenaean site, containing gates on the west, north, southeast, and south sides. These gates open toward Orchomenos, Anthedon, Mount Ptoios, and Thebes, respectively. It is noteworthy that the gates facing Theban territory directly are the most heavily fortified. This was the largest single building project undertaken in Boeotia in the entire Bronze Age, its magnitude highlighted even further by the drainage project and the wider program of regional fortification.

The northernmost part of the site, the melathron, appears the most palatial in character, with two megara, whose presumed use was for the top officials at the site (Iakovidis 2001, 40). Iakovidis writes that the melathron complex at Gla was not designed for a wanax and his retinue, arguing that its size, its accessibility, and the two megara do not match other known examples from Mycenaean palaces, specifically Mycenae, Tiryns, and Pylos. But why should we expect it to be the same? Similarities in palace plans and the singular notion of a megaron as a defining characteristic apply to only a few cases, all of which are in the Peloponnese (Younger 2005). No megaron has been revealed in the limited excavations of palatial buildings at Thebes (Aravantinos 2015, 21-22), and there are also double megara at Dimini in Thessaly (Adrimi-Sismani 2007) and at Kanakia in Salamis (Lolos 2012). We also know very little about Orchomenos and what a palace there might have looked like. Moreover, access to the melathron at Gla was in fact much more restricted than Iakovidis argues. Visitors would have had to come first through the "agora" area and then enter another set of gates before approaching and gaining access to the terrace on which the melathron was built. From the perspective of architectonic exclusivity (Smith 1999), access was more restricted than at the more canonical palaces of Pylos, Mycenae, and Tiryns (Thaler 2015; see also figure 3). Numerous frescoes add to the palatial character of the site (Boulotis 2015), and fragments of Linear B-inscribed stirrup jars suggest further importance at a regional and interregional scale (Iakovidis 1989, 1998, 2001).

The evidence from Gla and the Kopais therefore suggests a dramatic reorientation of the political landscape in LH IIIB. The most obvious aspect of this reorientation is a shift eastward, toward the Euboean Gulf and the especially fertile eastern part of the drained basin, culminating with a relocation of palatial authority at Gla. This is not to suggest a replacement for Orchomenos, which, as the ancestral center of the polity, no doubt remained important. Indeed, such political practices are well known in other settings-as, for example, in the movement of the ancient Macedonian capital from Aigai to Pella, with Aigai remaining the royal burial ground (Miller 2016, 291; Aelianus, Varia Historia 14.17). Such lasting significance may be reflected in the Treasury of Minyas, for example. But the level of investment in the layout of Gla and in the landscape around it suggests that this was conceived of and functioned as the primary administrative center of the polity of which it was a part. The well-fortified site at the center of a wider defense network provided a base that was at once closer to sea routes and to the agricultural production that was the central focus of Mycenaean palatial polities. This move is 
coincident with similar developments in Thebes, which renovated its own fortifications in LH IIIB (Aravantinos 2010, 54), perhaps in response to the appearance of the citadel at Gla so close to its border.

Such territorial tensions may help to explain the numerous destruction levels at Orchomenos, Gla, and Thebes at the end of LH IIIB. Gla was destroyed in LH IIIB2, along with the drainage works in the Kopaic Basin and the system of fortifications protecting it. ${ }^{15}$ This wiped out both the palatial authority at Gla and the agricultural resources of the Kopais. Spyropoulos (1974) notes that the palatial structure (an isolated megaron-like building) at Orchomenos was also destroyed at this time. Thebes seems to have suffered numerous destructions throughout the Palatial period; these have been variously dated to LH IIIA2-B1, LH IIIB1, and LH IIIB2 (Dakouri-Hild 2010b, 698; Aravantinos 2015).

Thebes and Orchomenos are much closer to each other than any other palatial centers in central Greece. Between them they have some of the richest agricultural land in the entire region. This proximity would have been a source of tension between these two polities, both of which seem to have pursued similar pathways to regional integration. Later literary traditions of conflict between the two polities may also be telling. From a spatial perspective, the drainage of Lake Kopais and the construction of the citadel at Gla would have changed the relationship between the Orchomenian and Theban polities significantly.

The wider context of these destructions and fortifications can be observed throughout the Mycenaean world. Palaces in the Argolid, too, seem to have pursued major fortification programs in LH IIIB. The scale of these projects and the large amount of time they would have taken to complete invite several potential explanations. In general, the walls and the blocks used to create them are far larger than would be needed to repel an invader or create a stable structure. In seeking to explain this architectural hyperbole, some have seen cyclopean fortifications (especially the Lion Gate at Mycenae) as imitations of Hittite citadels, geared toward a symbolic display of palatial power and an implicit control over human and natural resources (e.g., Maner 2012). Along the same lines, we might look to the Egyptian model of conscripted labor as a mode of state control during the nonagricultural season (Lehner 2015). Peer-polity interaction contributes a useful perspective as well, whereby rivalry and competition engender a set of shared symbolic practices (Renfrew and Cherry 1986). We might suggest more specifically that these monumental fortifications were built as a response to mounting tensions within or between Mycenaean polities. This may be viewed as a sort of symbolic "arms race" in interpolity relations, which can also be seen in patterns of fortification in the Maya world (Webster 2000) and in Classical Greek borderlands (Knodell, Fachard, and Papangeli 2017, 161).

15. This destruction date for the drainage works is problematic and is generally assumed, based on destructions and disuse at Gla and the surrounding sites. 
The destructions in Boeotia at the end of LH IIIB represent the culmination of a variety of conflicts within and between Mycenaean polities. Based on the archaeological evidence and territorial models presented here, it seems that a series of confrontations occurred between Thebes, Orchomenos, and Gla resulting in the overthrow of palatial structures and institutions at all three sites. It is possible (though by nature speculative and tangential to the arguments above) that some of these events may have entered the mythological record as stories of Herakles (a Theban) flooding the Orchomenian Plain by diverting the Kephisos and destroying the citadel of the Minyans (Orchomenos) (Salowey 1994).

This end, of course, should not be seen as absolute, and several abandoned sites were later reoccupied. What is important, however, is that this marks the final end of the palaces per se. While later occupation and building occur, palatial architecture, art, and burial are not revived, nor are any traces of central administration (Linear B). This suggests that these events should not be attributed solely to interpolity conflict. In addition to any destruction by external forces, these events also represent an internal rejection of the palatial system in Boeotia, most likely as a collective response to dissatisfaction with state authority.

\section{Euboea Between Two Worlds}

Euboea offers a complement and a contrast to Palatial Boeotia, especially in terms of its apparent diversity in modes of sociopolitical organization. While relationships between the two regions are evident in the settlement, material, and textual record, the island nevertheless seems quite apart from the world of the palaces. Euboea has significant remains from the Palatial Bronze Age at a number of locations, with different regional patterns observable in the northern and central parts of the island and the south remaining devoid of Late Bronze Age settlement (see map 9). I argue that the settlement patterns of Euboea represent various nonpalatial modes of sociopolitical organization that are contemporary with the mainland palaces (see also Knodell, forthcoming).

The north is home to several widely interspersed small-scale sites, mostly along the Euboean Gulf, with two further coastal jumping-off points to the bay of Volos at Oreoi (ancient Histiaia) and to the Sporades or wider Aegean at Kerinthos. Based on the small-scale, thinly dispersed evidence, we can guess that these were simple, agropastoral communities that were nevertheless in contact with each other and with some communities on neighboring coasts. Nevertheless, cyclopean-style walls at Kerinthos, extensive pottery remains at Lichas, and an impressive chamber tomb at Limni (the only one north of the central plain) suggest that there is more to be revealed about Mycenaean northern Euboea (Sackett et al. 1966, 108-9; Sapouna-Sakelleraki 1995, 1996; Loader 1998, 36-37; Nikolopoulos 2015; Lemos 2020).

The bulk of settlement evidence comes from central Euboea, which is clearly in dialogue with palatial spheres of the mainland (see map 10). Based on the current 
evidence, we can approximate perhaps seven or eight peer communities in central Euboea, at Psachna, Chalkis, Lefkandi, Amarynthos, Aliveri, Avlonari, and Viglatouri/Oxylithos. These can be broadly described as complex communities, with limited evidence for social stratification in the form of funerary architecture and a small-scale settlement hierarchy in which the aforementioned sites are locally distinct in scale. These sites were probably controlled by powerful family groups that expressed their status through elaborate tombs and exclusive material culture-similar to what is present on the mainland in the Early Mycenaean period.

The Psachna Plain was home to several Mycenaean sites, most notably at Aghios Ilias-a prominent hill that dominates the plain and two points of access to it from the north and east. No systematic excavation has been conducted, but Sackett and colleagues $(1966,54)$ considered it to have been a major site throughout the Mycenaean period, based on dense pottery scatters at and around the site and terracing on the southwest slopes. The prominent location, evidence of large-scale terracing, and higher density and extent of finds than at other sites in the area suggests that this was an important center at the top of a settlement hierarchy local to the Psachna Plain. Mycenaean sherd scatters are reported in fields through much of the broader area, from Politika in the north to Manika in the south (Sackett et al. 1966, 54-57).

Chalkis is more difficult to understand. As is the case for most periods, settlement remains are likely buried under the modern city, the largest on the island (Kalamara et al. 2015). Nevertheless, the extent of the community can be inferred from the dispersed remains, which include several chamber tomb cemeteries, the considerable wealth of which is on display in the Chalkis museum (Hankey 1952). Sackett and others $(1966,57-60)$ record no fewer than nine sites with prehistoric remains, and Pei (also called Dokos), located to the north, may have been the location of a tumulus or tholos (Sapouna-Sakellaraki 1996). ${ }^{16}$ The overall spread of remains across several parts of the modern city suggests a community of substantial size (Nikolopoulos 2015).

Lefkandi is less than 10 kilometers from Chalkis, in the southeast corner of the Lelantine Plain, near the outlet of the Lelas River. This was renowned agricultural land in antiquity, and the supposed cause of the mythohistorical Lelantine War between Chalkis and Eretria (see further in chapter 6). Already in the Bronze Age two major communities were located on opposite sides of the plain, in contrast to the palatial strategy in Boeotia of placing a dominant community in the center. This may suggest a more maritime orientation for Palatial period sites in Euboea, which was certainly the case in the Postpalatial period on the Euboean Gulf (see further in chapters 4 and 5). LH IIIC and PG building activity at Lefkandi has limited our knowledge of Palatial times, though the site was almost certainly

16. This interpretation is speculative at best, with no demonstrable tholos architecture and no documented Mycenaean finds that can be associated with the site. This badly degraded circular construction could also be a lime kiln. 
occupied. Sherratt (1980) suggests that LH IIIC pottery traditions started earlier in Euboea than elsewhere, which may in part explain the relatively small amount of clear Palatial material from Lefkandi and Amarynthos in comparison to the amount of material from the Postpalatial phases. This argument is supported by the fact that Lefkandi seems to have been the preeminent center for the export of LH IIIC pottery in the Euboean Gulf (see chapter 4, pp. 137-41).

Amarynthos is the only site in Euboea that can be plausibly identified in the Linear B tablets from Thebes, as later inscriptional evidence identifies the site as the sanctuary of Artemis Amarysia (Sapouna-Sakelleraki 1989; Krapf 2011; Fachard et al. 2017). This community was located at a crucial node in a central Euboean network of Mycenaean sites that stretches from the Psachna Plain north of Chalkis to the Kyme-Aliveri corridor (see map 10). Its position on the east side of the Eretrian Plain leaves it well positioned to exploit this important agricultural surface, and at this point in the Bronze Age it is clearly the dominant site in this area (Sackett et al. 1966, 64-66; Parlama 1979; Sapouna-Sakellaraki 1989). By contrast, only fragmentary Mycenaean remains have been found at Eretria and Magoula (Müller-Çelka, Krapf, and Verdan 2013). The location of Amarynthos gives it close access to both the maritime route of the Euboean Gulf and the land route from Aliveri to Kyme.

The Aliveri-Kyme corridor passes through several small valleys that contain the most impressive evidence of Mycenaean funerary activity on the island: a series of small tholos tombs at the sites of Velousia, Katakalou, and Evrimia and Paralia, both located at Oxylithos (see map 9; figure 4a and 4b; see also Sackett et al. 1966, 68-77). This natural route is marked by the course of a modern road; it was undoubtedly a significant passage in the Mycenaean period as well, connecting the Aegean coast with the Euboean Gulf.

Aliveri (Magoula) was almost certainly the principal settlement on the southern end of this corridor, where it could access agricultural land to the northwest (toward modern Aliveri) and to the east toward Velousia, Lepoura, and Katakalou. Recent work by the Ephorate of Antiquities of Euboea has revealed further Mycenaean chamber tombs of LH IIIB-C date in the vicinity. ${ }^{17}$ The tholoi of Velousia and Katakalou are both robbed, but their presence signals proximity to an important settlement (Sackett et al 1966, 68-71). These tombs may represent territorial claims of local elite families, but it is impossible to know if they belonged to the same community or polity. Farther south, near Dystos, Cyclopean walls have been documented at Loupaka, comprising the farthest south settlement remains documented in Euboea (Fachard 2009).

At Avlonari, located to the north, another substantial community seems to have occupied two hills (Palaiokastro and Antires) just west of the modern town. Wealthy tombs with gold objects, including a mask, were reported here, along with

17. See the press release here: https://www.culture.gr/el/Information/SitePages/view.aspx? $\mathrm{nID}=2348$. 


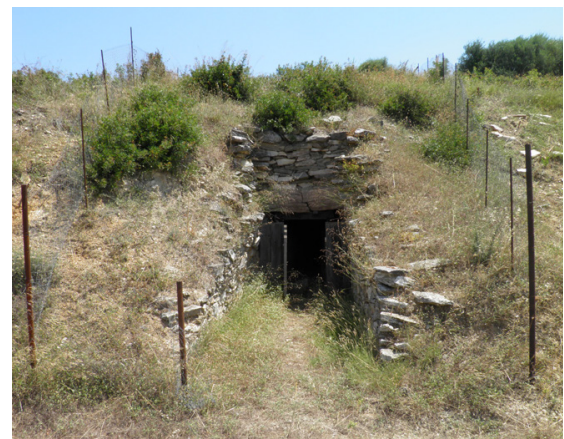

a

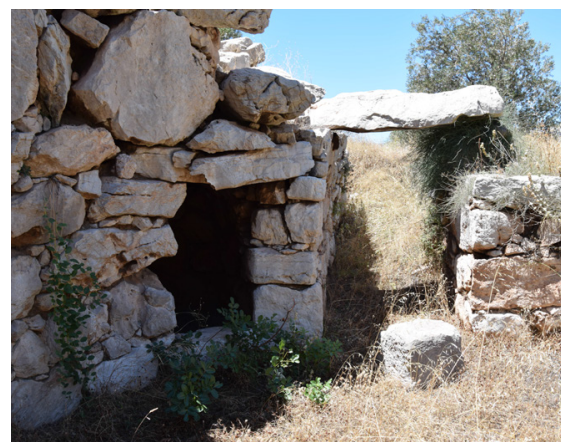

C

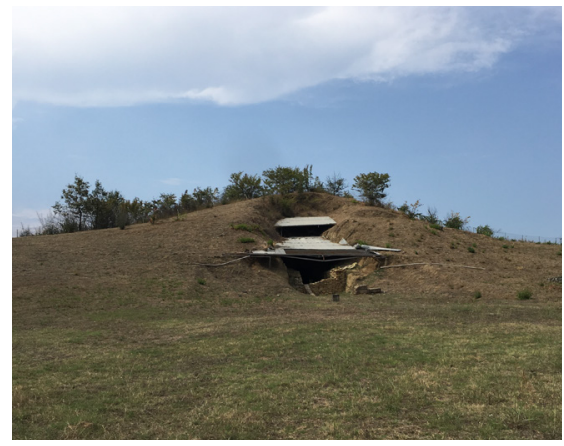

e

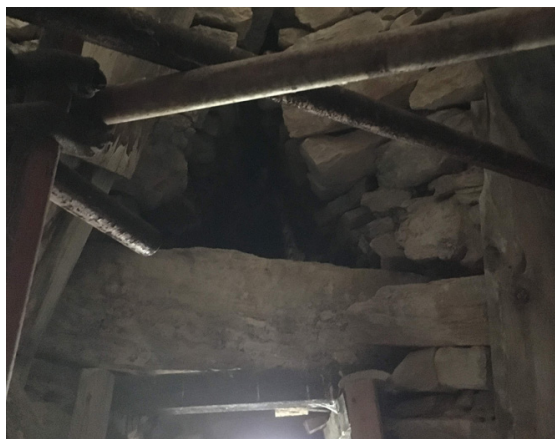

b

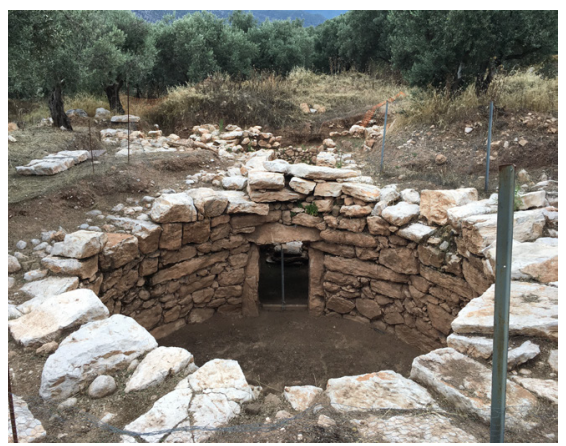

d

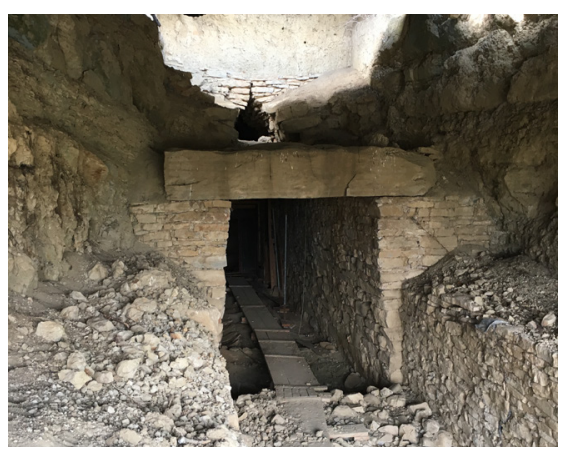

$f$

FIGURE 4. Some lesser-known tholoi of central Greece: Katakalou tholos on Euboea (a: exterior, looking northeast, and interior, from the chamber, looking southwest, and b: interior, showing relieving triangle and lintel); Tholos A at Medeon (c: from the chamber, looking west); tholos tomb found at Amblianos, near Amphissa (d: from above, looking northwest); tholos tomb at Georgiko (e: exterior, looking north, and f: interior, from the dromos, looking north) (image permissions courtesy of the Ephorates of Antiquities of Euboea [a and b], Boeotia [c], Phokis [d], and Karditsa [e and f], @Hellenic Ministry of Culture and Sports-Archaeological Receipts Fund). 
an LH chamber tomb cemetery, though the tombs themselves were never located and finds are unconfirmed (Sackett et al 1966, 71-73).

Near the modern town of Oxylithos, an acropolis site (Viglatouri/Kyme) overlooks a river outlet with a rich set of cemeteries-the two previously mentioned tholoi, one of which contained a Mycenaean dagger, and a chamber tomb cemetery at Moni Mantzari (Sackett et al 1966, 73-76). The wealth of remains at Oxylithos and its location on the bay of Kyme suggest that this was the intended destination of some 17 pillow-type oxhide ingots that were found just off the coast near Enoria in 1906, south of Kyme's modern harbor (Sackett et al. 1966, 75-76, n125; Lolos 2001b; Paschalidis 2007, 436). Notably, the wealthy funerary remains only date to the Palatial period, indicating that this site may have declined in significance for long-distance trade in Postpalatial times, as sites on the Euboean Gulf began to thrive. At Viglatouri, however, there is substantial continuity with a series of buildings from Middle Geometric and Protogeometric times (sometimes referred to as a heroön) above a Mycenaean megaron-like building (Sapouna-Sakellaraki 1998, 61-63; Kourou 2015, 96; Charalambidou 2017, 93).

The absence of Mycenaean material in southern Euboea remains somewhat troublesome. A-ma-ru-to and $\mathrm{ka}$-ru-to are associated with Euboea based on later place names, but this is complicated by uncertainties about their nature and exact location. While there is evidence of a substantial Mycenaean site at Amarynthos (see above), no more than a few sherds of Mycenaean material have been found in the entire region of Classical and later Karystos (Tankosić 2011; Cullen et al. 2013). This near complete absence is surprising for any part of central Greece, especially one that appears to feature in Linear B tablets. The location at the southern end of the Euboean Gulf, with the important Mycenaean centers of Thorikos, Brauron, and Marathon on the opposite coast, makes this all the more puzzling. It is possible that Mycenaean Karystos simply has not been found but this seems unlikely since the region has been subject to numerous campaigns of intensive and extensive archaeological survey since the 1980s (Keller 1985; Tankosić and Chidiroglou 2010; Cullen et al. 2013; Tankosić et al., forthcoming). Even if such a site exists but has not been found, it would need to be part of a wider regional system, of which we have no trace.

Overall, the pattern of settlement and social organization in Euboea varies dramatically across the island and also contrasts significantly with Boeotia. Small coastal settlements were found in the northern part of the island, with access to small agricultural plains and outlets across the Euboean Gulf or to the Sporades. The evidence does not provide much detail about sociopolitical organization, but these communities seem to have been less hierarchical and complex than those found in the central part of the island and do not seem to have been associated with any larger state apparatus. The communities of central Euboea seem to have been more complex, perhaps because of their stronger connections to the palatial mainland, and we might suggest several small, independent polities-small-scale 
complex communities that participated in Mycenaean modes of expressing hierarchy in terms of both central places and elite funerary architecture. Nevertheless, they seem to have been quite distinct from the polities of the mainland, and at any rate operated on a very different scale. An analogy might be found in the way some Early Mycenaean polities depended on relationships with Minoan palacesparticipating in wider trade networks and exploiting the profits of them locally, without being integrated into their political systems.

\section{Nonpalatial Worlds between Phokis and Thessaly}

Between Boeotia and the bay of Volos there is nothing that can be reliably identified as a Mycenaean palace. The overall distribution and organization of settlement varies considerably. Across these areas (East Lokris, Malis, Phokis), there is an increase in the number of sites from the Palatial period, but there is no "top tier" occupied by identifiable palaces, and there is no landscape- or region-wide evidence for centralized organization. In general, these patterns of organization seem to have more in common with the nonpalatial world of Euboea than with either of the palatial polities in Boeotia. As is the case with Euboea, these regions are discussed together as blocks of contiguous areas, without suggesting a uniformity of political organization.

Two main axes define the regions grouped together here. The first is the Great Isthmus Corridor Route, running north-south and linking together the modern towns of Lamia and Itea, the ancient regions of Doris and Phokis, and the Corinthian and Malian Gulfs (Kase et al. 1991). The second runs east-west to join the northern Euboean Gulf and East Lokris to the upper Kephisos valley and the corridor route (see map 10). The connectivity model highlights three main pockets of communities that cluster around these routes. The first is in southern Phokis, in the vicinity of Delphi. The second is a rather long, east-to-west arc that extends from East Lokris on the Euboean Gulf into northern Phokis at the regional crossroads of Kalapodi and from there into the northern Kephisos valley. The third group of communities surrounds Lamia in the eastern Spercheios valley.

In southern Phokis there is a triangle of settlement framed by the bays of Itea and Antikyra and the pass between Livadeia and Delphi. I suggest that these groupings represent two different political entities (and indeed types of entities). As indicated above, the bay of Antikyra seems the most likely access to the Corinthian Gulf for Orchomenos. Numerous sites along the way create a clear route linking the western part of the Orchomenian Plain (occupied by the palatial site itself) to the bay. Moreover, Tholos A at Medeon (figure 4c) demonstrates a particular connection to Orchomenos in the form of a rare side chamber, examples of which are found only at Orchomenos, Mycenae (in the Peloponnese), and Fourni (on Crete). The aforementioned study by Eder (2007) links this site to Elateia, perhaps via Orchomenos. The acropolis sites at Medeon and across the bay at Kastro tou Stenou would have provided defensible lookouts from which to monitor traffic 
on either side of the bay. Unfortunately, little more can be said about the settlement sites (Vatin 1969; Sideris 2014). One aspect of the location of these sites in the bay of Antikyra is a relative lack of agricultural land, suggesting that the presence of large-scale settlement here was linked mostly to its role as a port.

By contrast, the bay of Itea boasts abundant and productive agricultural land (McInerney 1999). Krisa was a citadel-like fortified site with cyclopean walling, towering high above the Krisean Plain. Kase $(1970,1972)$ has argued that it was a major land power that controlled the plain of Itea, its bay, and the land route north, which had Mycenaean road remains (see also Kase et al. 1991; Livieratou 2020, 817-18). A fortified harbor site is located at Kirra (Orgeolet et al. 2017). A second fortified site at Itea Glas protected the western access of the plain. This settlement system, with smaller sites in the surrounding area, suggests that an independent polity dominated the valley and bay, with immediate access to agricultural resources, the Corinthian Gulf, and routes to the north. Krisa seems to be the most significant of these three fortified sites, suggesting it may have occupied the top place in a hierarchy between them (though this is difficult to say with any certainty). In this case, the influence of Krisa may have extended some distance north toward Amphissa, where a large tholos tomb was discovered at the site of Amblianos (figure $4 \mathrm{~d}) .^{18}$

Concerning the wider political landscape, it is possible that Orchomenos could have extended its influence this far, though Medeon seems a more likely point of access from Boeotia. While Medeon is on the very edge of a modeled maximum for Orchomenian territory, the bay of Itea is well outside of that maximum, making this an unnecessary stretch to reach the Corinthian Gulf (see map 11). An independent polity here with a powerful Boeotian neighbor not far away may in part explain the heavy fortifications. The corridor route northward conveniently bypasses Boeotia to come out in the upper Kephisos valley, and from there connects to Malis and eventually to Thessaly. Common attributes of matt-painted pottery from Delphi, Kirra, Pefkakia, and the Spercheios valley seem to indicate connections all the way from Itea to Volos from at least the Middle Bronze Age (Dakoronia 2010). This centrality within a wider network of land and sea routes is certainly part of what made Delphi such an important place later in the history of the region. Some of the same geographical forces were no doubt at work at Krisa.

The upper Kephisos valley was occupied by a handful of small-scale sites during the Mycenaean period, including a larger center at Elateia with abundant evidence of elites (Bächle 2007). Jewelry, seals, and weapons were found in an excavated chamber tomb cemetery of some 91 tombs, indicating significant levels of wealth (and inequality) within the community (Dakoronia 2009; Deger-Jalkotzy 2009). Identical seals from this site and Medeon may also indicate a common political

18. The discovery of the tholos tomb at Amblianos, near Amphissa, was announced in the newspa-

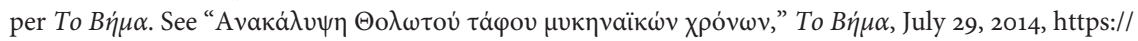
www.tovima.gr/2014/o7/29/culture/anakalypsi-tholwtoy-tafoy-mykinaikwn-xronwn/. 
link through Orchomenos (Eder 2007). Many of the tombs, however, date to the Postpalatial period and continue to be used into the Early Iron Age, demonstrating remarkable continuity not seen, for example, in neighboring Boeotia (see chapters 4 and 5). Wealthy grave goods from the Palatial period are seen elsewhere in the region only at Kalapodi and Zeli, which are both located to the east. From this evidence it seems likely that Elateia dominated the upper Kephisos valley, although we cannot rule out the presence of locally independent settlements elsewhere. The level of political integration across the landscape is largely unknowable based on the present evidence, and indeed Orchomenos may well have been influential or dominant in this area, too-as has been suggested by Eder (2007) and by the territorial model (see map 11).

Kalapodi occupies a critical crossroads between the upper Kephisos valley and East Lokris. Chamber tomb cemeteries in the surrounding area suggest that it was also an important region for settlement, with communities located at Kalapodi itself as well as at Zeli (to the west) and Golemi (to the east). It is noteworthy that both Delphi and Kalapodi-two early centers of regional cult activity-are located at major crossroads near the margins of modeled palatial territory. Cult activity at Kalapodi can now be traced back to the beginning of the Late Bronze Age, and at Delphi to LH III in the form of Phi and Psi figurines at the sanctuary of Athena Pronoia (Felsch 1981; Müller 1992; Niemeier 2016). Kalapodi, at least, seems to have functioned as a regional meeting place in much the same way such sites did in later periods. Other places probably functioned similarly as well, but within palatial territories these would have been rendered obsolete by the concentration of cultic and other social gatherings at the palaces themselves. In a way, then, such regional sanctuaries could have existed only outside the realm of the palaces, and they continued to function as loci for the agglomeration and dispersal of goods and ideas. The communities in the vicinity obviously benefited from this as well.

East Lokris seems to decline in the Mycenaean Palatial period, perhaps because it was overshadowed by the palaces of Boeotia. Kramer-Hajos $(2016,100)$ has referred to this process as the "domestication of the warrior," in which the warrior classes represented in the elite burials of the Early Mycenaean period were made largely obscure. Yet burials represent only certain aspects of sociopolitical affairs. It seems likely that the palaces of Boeotia were indeed creating imbalances in the consumption and distribution of prestige items, but the continuity of cultural practice between Early Mycenaean times and the Postpalatial period suggests that life in East Lokris went on with relatively little change. While Lokrian society was no doubt impacted by the palaces, it need not have been through political domination.

There are two east-west axes of communication that run from the Euboean Gulf to the Corinthian Gulf (see map 10). I suggest that one of these-the one running between the bay of Antikyra and Larymna-was largely controlled by the palatial polity of Orchomenos. The northern axis is more difficult to understand, since it represents a settlement network made up of communities with considerably 
less visible variety in size and hierarchy. To be sure, differentiation is still present, but here we might imagine a situation more like that found in central Euboea, with relatively small communities and territories organized on a local scale, and with limited evidence for social differentiation. Certain major sites are located along this axis, at Krisa, Kalapodi, Elateia, and Mitrou, which probably attracted palatial attention and were variously influenced by or perhaps in some cases incorporated into the palatial world.

Finally, the Spercheios valley and the region of Lamia (ancient Malis) comprise another distinct hub of settlement. There is little evidence for settlement between the upper Kephisos valley and Malis, there being only a few sites located along the principal land routes. A handful of sites dot the landscape on the southern end of the plain of Lamia, in the foothills of Mounts Kallidromon and Oita, occupying the major points of access to the plain and controlling passage into and out of it. Lamia itself seems to have been the dominant site in the region, as through much of its history, with additional, apparently wealthy, communities populating the Spercheios valley, especially at Kompotades, Vikiorema, Tymbanos, and Platania (Dakoronia 1990, 2009; Papakonstantinou 2009). Positioned at a strategic entry point to the valley, Hypati represents a sort of western limit. The organization of settlement in the area is difficult to discern, not least due to a lack of full publication for most of the Mycenaean material thus far only briefly reported. The general impression follows that of other nonpalatial areas, with a few distinct communities perhaps dominated by elite families - a pattern consistent from the Early Mycenaean period through LH IIIC. There is no clear center, although Lamia is of course a likely candidate for a central place of some kind. Without evidence for regional integration, and with dispersed communities represented by wealthy cemeteries that seem more or less evenly distributed and on par with one another, this looks similar to the nonpalatial situations of East Lokris, northern Phokis, and Euboea. On the other hand, there is a significant clustering of chamber tomb cemeteries around Lamia, suggesting that there may have been a principal site located there (as in later periods), perhaps analogous to the situation with Krisa in the bay of Itea.

\section{Mycenaean Thessaly}

Often called the "periphery," Thessaly is on the margins of what is traditionally defined as the Mycenaean world (Feuer 1983, 2011, 2016a, 2016b; AdrimiSismani 2007). Feuer (2016b) characterizes the region as existing in three parts: (1) a core zone around the north and west sides of the Pagasetic Gulf, (2) a border zone extending up the Enipeus and Pineios river valleys to Trikala and Larisa, and (3) a frontier zone beyond that. The defining criteria are essentially geographical-proximity to the sea and the palatial centers in Volos afforded opportunities for interface with the wider Mycenaean world to the south. The inland plains of central, western, and northern Thessaly were more extensive and 
set apart. Feuer's assessment is largely reflected in the distribution of material culture, and this pattern was used also to define the northern limits of the study area investigated in this book (see map 2).

A dense concentration of activity is located around the bay of Volos, with three sites exhibiting palatial aspects of material culture: Dimini, Kastro Volos (Palaia), and Pefkakia. Pefkakia was a major site with evidence for habitation, various aspects of craft production, and long-distance trade. This was most likely the principal port of the region, situated at the entry point of the Pagasetic Gulf. The current excavator of the site has suggested that this is the port of Dimini, which she and others have identified with legendary Iolkos (Batziou-Efstathiou 2015; see also Adrimi-Sismani 2007, 2016).

Dimini is the most intensively excavated of the major Mycenaean sites in Thessaly (Tsountas 1908; Adrimi-Sismani 2017, 2018), and it has the most characteristics associated with Mycenaean palaces. A double megaron structure is present, with a possibly shared courtyard separating two parallel architectural complexes (see figure 3). This appears to be a palatial settlement with elite structures, workshops, and storage facilities. Linear B has been found at the site as well in the form of a stone weight inscribed with three signs (Adrimi-Sismani and Godart 2005). Two tholos tombs signal elite activity in the funerary realm. The Lamiospito tholos and an early megaron under Megaron A have been dated to the end of the fifteenth century, or LH IIIA. Subsequently the double-megaron complex was built, along with the second tholos. The palatial complex was destroyed in LH IIIB2/C. Curiously, no Mycenaean fortification has been discovered at Dimini.

The final palatial location is at Palaia, or Kastro Volos, in the heart of the modern city of Volos (Theocharis 1956, 1957, 1960, 1961; Skafida et al. 2016). As in the case of Thebes and Orchomenos, the Mycenaean site is covered completely by the modern city. Monumental buildings from the fifteenth century BCE have been excavated, as well as two tholos tombs, at Kapakli, immediately northwest of Kastro Volos, and at Kazanaki, on the Volos ring road some distance to the north (Pelon 1976, 243; Adrimi-Sismani and Alexandrou 2009; Papathanasiou 2009). While the architecture and layout of Mycenaean Volos are less well understood than at Dimini, the finds are in some ways more impressive, including exceptionally wealthy burials in the tholos tombs (the tholoi at Dimini were looted long ago) and Linear B tablets (Stamatopoulou 2011, 77-78; Skafida, Karnava, and Olivier 2012). The Kazanaki tholos, moreover, had seven Linear B signs inscribed on its lintel (Adrimi-Sismani and Alexandrou 2009). A final interesting feature of Kastro Volos is the continuity of occupation well into LH IIIC, which does not happen at Dimini and Pefkakia (both lasting only until LH IIIC Early).

The political landscape of the bay of Volos is tied to the history of these three sites, but their specific relationships are more difficult to discern. Pantou (2010) provides the most sophisticated analysis of the political organization of the region, proposing a heterarchical model in which power may have been shared between 
these three centers, the collective influence of which may have extended well beyond the bay. She points out, however, that the "palatial" remains at Dimini and Kastro Volos are on a somewhat lower order of magnitude than those found at other palatial centers. The size and sophistication of buildings is less than at other known palatial sites-there are no remnants of frescoes, no traces of fortifications, and the evidence for Linear B administration is extremely limited (Pantou 2010, 395-96). There are at least three possibilities, then, for the political organization of the landscape: (1) a distributed sense of political authority representing a single polity in the bay of Volos; (2) a model in which centralized authority shifts in different phases between competing independent centers; or (3) two or more independent polities coexisting for the most part independently. ${ }^{19}$ The adoption of some aspects of Mycenaean palatial systems (Linear B at Volos and the architectural complex at Dimini) suggests that there would have been some interest in centralizing authority and integrating large agricultural landscapes in two different places. The relatively small plain of Volos would have provided limited opportunity for agriculture, but there are other, larger surfaces that fall easily within a modeled territorial extent (see map 11). These tracts of land are located chiefly to the northwest, in the vicinity of Lake Karla (ancient Boibeis), and to the south, toward Almyros. These areas also fit neatly within the "core" zone of Mycenaean material culture as modeled by Feuer (2016b).

The rich agricultural landscape of Lake Karla may well have served as a sort of breadbasket for the palatial entity (or entities) of the bay of Volos, with Velestino (ancient Pherai) occupying an important crossroads in between, where another major plain opens up southward to Aerino. In the network model (see map 10) this group of sites fits together reasonably well. The massive fortifications at Petra, if their estimated extent of about four kilometers is accurate, are the largest Mycenaean fortifications in all of Greece (Hope Simpson 1981, 165), though this site is largely uninvestigated.

To the south, it is possible that palatial influence extended to the plain of Almyros as far as Halos, but the scale of known Mycenaean remains in this area pales in comparison to what is found to the north (see maps 6 and 10). The distribution of sites between Phthiotic Thebes and Halos suggests that the plain was being exploited in Mycenaean times but tells us little about its broader political relationships (Stissi 2004). South of here a few isolated settlements may have prospered as small-scale polities taking advantage of their dual location on land and sea routes. Pteleon sports an impressive cemetery comprised of five small tholos tombs, and it is well positioned in a sheltered bay at the entry point to the Pagasetic Gulf, on the one hand, and at the main land route to Lamia, on the other (Feuer 1983, 44).

19. A range of models has been suggested also for the crowded palatial landscape of the Argolid (see, e.g., Vermeule 1964; Kilian 1988; Cherry and Davis 2001; Demakopoulou 2007; Burns 2010). Mycenae and Tiryns are both clearly major palatial sites there, and they are accompanied by significant, if poorly preserved, remains at Argos and Nafplio, and another major palatial site (if not necessarily a proper palace) at Medea, which also has very wealthy cemeteries (see map 9). 
To the west, another group of communities in the vicinity of Pharsala was distinct from those of the Pagasetic Gulf, both in network terms and in falling outside the modeled territorial extent for a polity centered in the bay of Volos. Pharsala itself boasted a significant Mycenaean settlement, one marked by continuous use through the Early Iron Age as well (Katakouta 2009). Scattered remains are documented at a variety of other sites on the eastern edge of the western Thessalian Plain, occupying and exploiting this agricultural land; from these one could also move south to the western end of the Spercheios valley. This is the first group of communities that Feuer (2016b, 190) identifies as falling within his border zone, which extends up to Karditsa and Larisa, both of which also have important Mycenaean sites - not least the impressive tholos tomb at Georgiko (figure 4e and 4f) but fewer shared attributes with the "core" areas that connect most clearly to the rest of central Greece.

In the background of all of this we must consider the dearth of systematic surveys that have been carried out in Thessaly (see table 3). While a good number of sites have been documented, and most major sites are probably known, the lack of systematic study (1) across the landscape as a whole and (2) at sites of major significance leaves the picture somewhat unclear. For example, the scale of fortification architecture at Petra and the monumental tholos at Georgiko suggest that these "border" zones are far from peripheral and demand further, more detailed attention in order to elucidate issues of chronology, settlement patterns, and social organization. ${ }^{20}$ What is clear, however, is that the political landscape of Mycenaean Thessaly is quite distinct from what we have seen elsewhere, although there are some elements there that are apparently similar to palace-oriented Boeotia and others that resemble the still poorly understood situation in the bay of Itea.

\section{Integration vs. Fragmentation: The Question of Athens and Attica}

I turn last to Athens and Attica. While it seems that more information should be available for the region in the Palatial period, the picture of sociopolitical organization we have here is in fact just as complicated as it is in Thessaly, and perhaps even more so (Osborne 2020). Traditionally, Athens has been considered a palatial center in the mold of Pylos, Mycenae, and Thebes. There is evidence of a Mycenaean fortification on the acropolis, a "secret spring" comparable to the one at Mycenae, and wealthy burials in various places, most notably in the area of the Classical agora (Mountjoy 1995a). ${ }^{21}$ The acropolis is the natural choice for such a settlement at Athens and the fortifications and evidence of a double gate below the Nike bastion are strong indicators of a significant palatial site (Wright 1994).

20. The internal relationships of communities in southern Thessaly have been emphasized here, along with their relationships farther south, but there is also much to be said about the northern interfaces (see Feuer 2016a and 2016b).

21. For an overview, see Mountjoy 1995a; Privitera 2013. For the Acropolis, see Iakovidis 1962, 2006; Wright 1994; Mylonas Shear 1999. For the spring, see Broneer 1939; Gauß 2003; Van Damme, forthcoming. For the agora, see Immerwahr 1971. 
Most other architectural evidence has been obliterated by later building, though it is telling that builders during the Classical period left parts of the Mycenaean walls deliberately exposed-a demonstrable connection to a legendary Bronze Age past, which was likely also connected to Athenian notions of autochthony (Hurwitt 1999, 82).

The evidence from the acropolis and the settlement and burial evidence around Athens suggest a major polity, likely something resembling other Mycenaean palatial sites. The form, organization, territory, and relationship to other sites in Attica are less clear, not least since several other sites in the region appear to have functioned as politically independent entities. These already muddy waters are sometimes disturbed even further by invocations of the mythical synoecism of Theseus. Thucydides (2.15) says that until the time of Theseus the inhabitants of Attica had independent communities and councils and were then unified under the legendary hero king. This should not, of course, be the basis of an archaeological history, and in recent years, archaeologists have increasingly questioned the idea of a unified Attica in the Bronze Age. They have done so based on distinct and impressive concentrations of finds at several other prominent sites, most notably Eleusis, Thorikos, and Marathon (see, e.g., Stubbings 1947; Papadopoulos and Kontorli-Papadopoulou 2014; Cosmopoulos 2014, 2015; Papadimitriou 2017; Papadimitriou and Cosmopoulos 2020).

In the network models employed here, distinct clusters of sites occur in several places, often with one community that clearly stands out in the settlement hierarchy (see map 10). The first- and second-order sites that likely represented independent political entities are Athens, Eleusis, Marathon, and Thorikos. The Mesogeia Plain of central eastern Attica is more complicated, with major sites at Brauron, Spata, and Koropi, which also may have represented independent polities. Finally, Salamis seems to have boasted at least two major sites on opposite sides of the island, at Kanakia and Ampelakia, one of which (Kanakia) is described by its excavator as a palace in its own right (Lolos 2007, 2012).

Continuity at most of these sites from the Early Mycenaean period suggests that their rise cannot be linked to a particular palatial center, as we saw in Boeotia. There is in fact some decline observed in certain communities in LH IIIB, which has led some scholars to suggest a centralization of regional resources at Athens, though this in itself does not constitute evidence for regional integration (Papadimitriou and Cosmopoulos 2020). Supposing Athens did expand its influence beyond the Athenian basin at some point in the Late Bronze Age, it is interesting that the same territorial model applied to Thebes would put Thorikos and Marathon outside its influence and Eleusis on its outskirts (see map 11). While Athens does seem to have been the largest, most powerful site in Attica, perhaps by an order of magnitude, there are numerous reasons to think its political territory was limited to the basin of Athens, with Mount Aigaleo providing a northwestern boundary, Mount Hymettos on the east, and the Parnes range to the north (see 
map 8). The Menidi tholos (at Acharnai) and its surrounding remains perhaps represent an extension of Athenian authority to the north, in order to control the agricultural zone they inhabit, though it is impossible to tell according to the presently available evidence. This is perhaps analogous to the situation between Orchomenos and Medeon, the latter of which provided access to the sea and was accompanied by monumental tombs as markers of territory and authority. At any rate, between the sizable agricultural extent of the basin of Athens and the access to the sea via Phaleron and Piraeus, a community at Athens would have occupied a strategic position similar to palatial centers elsewhere.

Thorikos boasts some of the most impressive Mycenaean remains in Attica. Between the wealth of funerary and settlement evidence at the site and its position to exploit the abundant metal resources of the Lavriotiki, its significance cannot be overstated (Laffineur 2010). Beyond the acropolis settlement of Velatouri, five monumental tombs, including two tholoi, signal a level of complexity and prosperity beyond any other community in eastern Attica. Pottery evidence from Mine 5 demonstrates mining activity at the site in LH IIIB2/C (Mountjoy 1995b). In the context of the spatial models presented here, Thorikos is also very much set apart from the rest of Attica (see maps 10, 11). It falls well outside even a sort of "maximum" territory for Athens, and it is also quite separate from the communities surrounding Brauron to the north and Kiafa Thiti to the northwest. The geographical orientation of Thorikos is seaward, toward Makronisos and Kea, providing convenient jumping off points elsewhere. It is also telling that Mycenae exhibits significant connections to Thorikos from the Shaft Grave period onward. Lead Isotope Analyses (LIA) of silver from several locations in the Mycenaean world (Mycenae, Vapheio, Athens, Menidi, Perati, and Thorikos) were used to argue that the Lavriotiki was almost the exclusive source for this metal during Mycenaean times (Stos-Gale and Gale 1982), though later analyses suggest that northern Greece, namely the Chalkidike, was a major source as well (Stos-Gale and Macdonald 1991, 272-79; see also Papadimitriou 2017). The large number of Cretan imports at Thorikos also suggests that this was an important destination for traders, both for metals and as an entry point to the Euboean Gulf. Control over the mines at Thorikos remains a key issue for the prehistory of eastern Attica.

The central Mesogeia Plain and coasts of eastern Attica were home to fairly dense occupation in the Bronze Age, which is well documented by the volume and quality of archaeological fieldwork conducted by the Ephorate of Antiquities in recent decades (see, e.g., Kakavogianni 2009; Vasilopoulou and KatsarouTzeveleki 2009; Andrikou 2015; Stefanis 2015; Papadimitriou et al. 2020). An important cluster of sites has been detected in the vicinity of Spata, located in the center of the plain. The influence of Spata may have extended as far west as Glyka Nera, although such an inference is based purely on proxemics (Grammenou 1996; Kakavogiannis 1999-2000; Kakavogianni 2003). Papadimitriou (2017) has argued that the significance of Spata might relate to its presence on a land route that links 
Thorikos, Spata, Menidi, and eventually Boeotia (see also Fachard and Knodell 2020). This model may also explain a diachronic pattern according to which the Mesogeia Plain near Spata is the most densely occupied in the early Palatial period, and which coincides also with the construction of the Menidi tholos. The palatial trappings of Athens only appear at a relatively late stage (LH IIIB2).

Settlement connectivity models show clusters around prominent sites at Marathon, where settlement evidence at Plasi, MH-LH III tumuli at Vrana, and the tholos tomb (with horse burials) at Arnos signal a major occupation both in Early Mycenaean times and during the Palatial period (Polychronakou-Sgouritsa et al. 2016). ${ }^{22}$ A significant long-term presence in the area is represented in the form of large-scale cemeteries from the Early Bronze Age onward (at Tsepi), and it is likely that this community remained consistently independent, situated as it was on an ample coastal plain, located on the important sea route of the Euboean Gulf. It was also the best positioned site in eastern Attica to connect to Boeotia by land, via Aphidna.

The wealthy graves of Brauron and the associated settlement indicate habitation from the MH period until LH IIIC, with a peak during the Palatial period of LH IIIA-B (Papadopoulos and Kontorli-Papadopoulou 2014). Again, continuous habitation and a flourishing community in the Palatial period suggests a consistent political trajectory rather than one in which an inland power came to dominate at some point. ${ }^{23}$ In the LH IIIC period there is a shift in concentration of tombs, wealth, and imported goods to the next bay south (Porto Rafti) at Perati (Murray 2018a).

In the southern part of the Mesogeia, fortified communities at Koropi (Kastro tou Christou) and Kiafa Thiti may have represented still further independent sites, though gaps in the occupational history during the LH III period may suggest some sort of abandonment after the Early Mycenaean period (Maran 1992, 1993; Privitera 2013, 124). Lohmann (2010) has suggested that Athens may have integrated these centers into its own remit at this point.

Turning to western Attica, the central structure "Megaron B" at Eleusis seems to have been an important political/religious space within a much larger complex in use from the Early Mycenaean period to LH IIIB/C Early (Cosmopoulos 2014). The site itself occupied an important land route between Athens, Thebes, and the Peloponnese, as well as the protected port of the bay of Eleusis. The agricultural resources of the Thriasian Plain are also quite broad, which forms an interesting background to mythic associations with Demeter and Persephone, as well as to historical efforts by Athens to incorporate this space into its own territory, most

22. Current excavations at Plasi have been undertaken by a team from the University of Athens since 2014. See Marathon Excavations, accessed December 4, 2020, http://www.marathonexcavations .arch.uoa.gr/.

23. It should be noted, however, that most of the evidence from eastern Attica is in the form of tombs; settlement excavations have been extremely limited. 
probably signaling earlier political independence. ${ }^{24}$ Eleusis is also home to the only Linear B that has been found in Attica in the form of an inscribed stirrup jar with the sign wa. This has been interpreted as an abbreviation for wa-na-ko-te-ro (of the wanax), perhaps a leftover from a larger consignment destined for Thebes (Cosmopoulos 2014, 458; Papadimitriou 2017). Just as Thorikos or Marathon make natural points of entry from the sea to inland places in eastern Attica, so too does Eleusis for western Attica (Fachard and Knodell 2020).

Finally, Kanakia, on Salamis, clearly represents a major center (Lolos 2012), and it is unlikely to have been tied to another polity-for example, Athens or Eleusis. We know of no examples of mainland polities extending their influence to sites on islands (discounting such a relationship between Euboea and Thebes, as I argue above). Whether Kanakia should be considered a "palace" is another matter. It probably should not be, at least not when compared to larger centers. This site is much smaller in size and apparent territory than other palaces, and there is no evidence of Linear B, in spite of systematic excavations across the site. Building $\Gamma$ is described as yet another "double megaron" building (compare to Dimini, Gla) that may have been the seat of a local ruler. There is also some evidence for specialized workshops and a small plaque stamped with the cartouche of Rameses II. The seaward orientation of the site suggests that this, rather than the agricultural inclinations of the mainland palaces, was its priority. In this way (and in terms of size and chronology) Kanakia had more in common with places like Pefkakia or later centers of the LH IIIC period-for example, at Lefkandi, Kynos, or Koukounaries. It is doubtful that this site exercised control over other large sites on the island (at Salamis Town and Ampelakia), considering the seaward orientation of Kanakia and the island topography, which set it quite apart from these other places. The cemetery of 204 chamber tombs on the other side of the island, at Ampelakia, suggests another major community there (Hope Simpson and Dickinson 1979, 204). While Salamis is located conveniently to form nearby connections to Eleusis, Megara, and Athens, we must also consider its position in the Saronic Gulf and its demonstrable connections to Aegina and the Argolid, especially the

24. There is considerable debate concerning the point at which Eleusis (and the rest of Attica in general) was incorporated into the territory of Athens (Padgug 1972; Diamant 1982; Mills 1997). While certainly part of a common cultural sphere from the Mycenaean period onward, clear signs of political incorporation are not present until the seventh century, possibly even the sixth; these are based on textual sources, which suggest that Eleusis was independent and allied with Megara before it came under Athenian control following a series of conflicts. The "synoecism of Theseus" may suggest an earlier date in the realm of mythohistory (Thucydides 2.15), which of course should not be accepted as fact. At any rate, even if we did follow the mythohistorical sequence, the period of conflicts between Athens and Eleusis would follow the supposed synoecism. Osborne (1994, 152-54) has argued that we should probably not see the synoecism of Attica as a singular event or series of events at all; rather, we should consider that Eleusis was part of Attica as long as Attica was an entity. This of course does not answer the question of when Attica became an entity. 
sites of Kolonna, Aghios Konstantinos (Methana), and Korfos-Kalamianos (in the eastern Corinthia) (Tartaron 2013, 237-43).

The overall picture in Attica, then, seems to be one of fragmentation, though it is difficult to interpret the evidence with certainty. Athens is in the center-in all likelihood as a significant but not a hegemonic regional power. Its territory would have extended for some distance around it, but this territory was probably limited to central Attica. An equally important center was at Thorikos, which exploited the metal resources of the Lavriotiki from a very early date. The maritime orientation of Thorikos was probably also an important centralizing force for it to connect northward via the Euboean Gulf, southward into the Cyclades, and westward into the Saronic Gulf. Thorikos is also our most likely candidate as an early entry point for certain elements of elite Mycenaean culture (e.g., tholos architecture) coming first from Messenia or Crete, and perhaps later from the Argolid. Further major communities were located on Salamis and at Eleusis, at Marathon, and in the vicinity of Brauron. In general, the pattern of central sites is neatly dispersed across the landscape in natural habitation zones. Their geographic positions, the distribution of smaller sites around them, and their centrality in the network models presented above suggest political independence, at least in the absence of evidence for unification. While much of Attica was engaged with the palatial worlds in close proximity to it, Attica outside of Athens cannot really be described as palatial. And even Athens, in the absence of Linear B documents or a clearer set of architectural characteristics, is difficult to describe with any certainty. The pattern in Attica, as well as in the other regions of central Greece described above, suggests that palatial territories and organization must be considered the exception, rather than the rule, when it comes to the political landscapes of Mycenaean central Greece.

\section{PRODUCING PALATIAL CULTURE: \\ TECHNOLOGY AND POLITY}

The foregoing discussion demonstrates the diversity of contemporary political landscapes in the Mycenaean world, chiefly through archaeological evidence concerning the scale, organization, and connectivity of regional settlement systems. Certain technologies also played a significant role in the perpetuation of political authority. The Palatial period-in palatial areas-witnessed an intensification and a centralization in modes of production, especially concerning agriculture and prestige goods. New technologies of writing were distinctly palatial, while aspects of craft production-for example, pottery-exhibit both continuity of tradition and expansion in scale.

Economies of production are revealed in some detail in the Linear B tablets from Pylos and Knossos, which describe regionally produced goods coming into the palaces, including leather, livestock, timber, grain, olives, and wool. This has 
allowed researchers to reconstruct aspects of palatial involvement in different types of agricultural and craft production. ${ }^{25}$ While the Thebes tablets are less complete, they signal the same type of centralized authority, which took in enough agricultural produce for the palace to operate and also to impose itself across its territory.

It is no coincidence that Mycenaean centers are exclusively located on large fertile plains (Bintliff 1977b). Palaces were involved, both directly and indirectly, in the mobilization of resources through taxation, direct production, and a variety of unrecorded transactions (Halstead 2007, 67; Nakassis, Parkinson, and Galaty 2011; Nakassis, Galaty, and Parkinson 2016). Agricultural products included the predictable mix of grain, olives, and vines, as well as flax, honey, spices, and sheep. It is tempting to draw a direct association between the most prominent palatial centers in the Mycenaean period-Orchomenos, Gla, Thebes, Volos, and Athensand the size of the plains they inhabit. Beyond the palaces, there is no doubt that substantial agricultural plains also coincide with Mycenaean sites of prominence; this is also the case for Oreoi, Psachna, Chalkis, Amarynthos, Krisa, Marathon, and Athens.

Networks of agricultural production that tie in to palaces are complex. Mycenaean economies were not redistributive in a strict sense but operated rather by systems of taxation that would support the palace. This system was still quite integrative, though, drawing in animal and agricultural products from throughout the hinterland and the surrounding territories. In some cases, the influx of products to the palace seems to represent a form of taxation, but in other cases it may represent an exchange-based relationship, as was likely the case for Amarynthos and Karystos, for which the volumes (one pig each) in transit are very small. The Thebes evidence suggests that the immediate surroundings of the palaces were the most integrated into this agricultural system, as is made clear by the relative proximity of second-order centers and the greater prominence of nearby places in the Linear B tablets. What we have, then, is a fairly integrated local network of agricultural production, partly overseen by the palace, partly controlled through taxation or exchange, and partly used to support the center and its related industries. Such accumulations were also used for state-sponsored public activities, such as feasting, itself an exercise in integration, group formation, and placemaking (see also Small 2019, 89-91). Moreover, palatial architecture, especially the presence of storerooms in close proximity to the megaron, suggests that there was at least some symbolic aspect to certain types of agricultural storage-most likely involving oil and wine-as Hamilakis (1996) has argued for Bronze Age Crete. In sum, it is not necessary for Mycenaean agricultural systems to be fully

25. Halstead $(1992,2007)$ has been particularly active on this issue, and his interpretations are widely accepted. He emphasizes especially the complexity of production, networked across a regional landscape. See also Palmer 1992, 1994, 1998-99, 2001, 2008; Killen 1998, 2015; Nakassis 2013a; Palaima 2015. 
redistributive in order for them to be highly integrated and crucial for the maintenance of symbolic and economic authority.

Certain aspects of craft production were tied closely to the palace as well. At Thebes, these included wall-painting, jewelry production, certain types of stoneworking, ivory and boar-tusk working, potting, and glass production (DakouriHild 2005, 181-86). At Dimini there is also evidence of jewelry manufacture, ceramic production, and metal and ivory production (Adrimi-Sismani 2007, 164). The production and the use of seals in the integration of political networks seem also to have been key practices, especially in Boeotia, Phokis, and East Lokris (Eder 2007; Kramer-Hajos 2016, 84-100). Most of these technological processes are multiscalar by nature, involving materials and knowledge that coalesce in the palaces from a variety of locations. The influence of Minoan wall painting on Mycenaean industries is well known (Chapin 2010, 230) and Brysbaert (2008a, $2008 \mathrm{~b}$ ) has indicated similarities in production techniques between Thebes, Gla, and Orchomenos, raising the possibility of itinerant craftsmen operating regionally. Brysbaert (2008a, 2761) also notes a general decline in quality from LH IIIA to LH IIIB contexts, suggesting, perhaps, that Minoan craftsmen or influence may have been directly involved in the earliest Palatial wall paintings and not in the later ones. Moreover, the use of Minoan aspects of material and visual culture by the Mycenaean elite played an important role in state formation (and maintenance) processes, and the production of similar objects in palatial contexts seems to have been a major priority for the individuals controlling the palaces.

Of course, Minoan-Mycenaean connections are only one aspect of these technological networks (see, e.g., Brysbaert 2011). Raw materials, especially metals, had to be procured, often over long distances, as did other resources such as ivory and obsidian. Gold most likely came from Macedonia or Thasos, perhaps through a connection with the site of Thessaloniki Toumba, which exhibits evidence of gold melting and production (Vavelidis and Andreou 2008), or Methone, located on the Haliakmon delta and which also has ample evidence for early gold-working, as well as over 20 Mycenaean tombs. ${ }^{26}$ It now seems clear that the Lavriotiki, the Cyclades, and the northern Aegean were all important sources for silver during the Bronze Age (Stos-Gale and Macdonald 1991, 272-79; Kayafa 1999). This has major implications for interactions between the Mycenaean "core" and the northern Aegean (Papadopoulos 1996b, 173-74; 2005, 589), implications that are reinforced by the presence of Early Mycenaean pottery at Torone (Cambitoglou and Papadopoulos 1993; Morris 2009/2010). Central Greece, significantly, has both land and sea routes through which communication between northern Greece and the Mycenaean heartland of the Peloponnese would have had to occur.

For copper, the Lavrio and Cycladic sources seem to have been used more in earlier periods than later ones (Bassiakos and Tselios 2012). The canonical

26. The ongoing work of the Ancient Methone Archaeological Project has shed much new light on the settlement history of the area (Morris et al. 2020). 
representative of the Late Bronze Age copper trade is of course the oxhide ingot, examples of which are found across the Mediterranean and in several parts of Europe (Sabatini 2016). There is also a widely supported argument based on lead isotope analysis (LIA) that all oxhide ingots in the Mediterranean with a date of 1250 BCE or later likely came from Cyprus (Knapp 2012). Kayafa (1999, 405), on the other hand, shows that the Cyclades and especially Lavrio were important sources for many of the finished objects dating to the LH III period, even if most ingots came from Cyprus. While specifics are frequently debated, broad trends, such as a marked rise in Cypriot copper production in the Late Bronze Age and its impact on the Aegean, are clear.

Wood for fuel and construction were universal needs, but they were particularly important to the palaces for both construction and craft production. With the expansion of pyrotechnologies necessary for the manufacture of pottery and metals, fuel needs would have increased dramatically, especially at first and second order sites. While wood that could be used for fuel was fairly widely available, larger trees for monumental construction and shipbuilding had to be sought in the more thickly forested areas. Northern Euboea was known as an important source for timber and fuel in later times, as was the northern Aegean.

A diverse range of geographical connections was necessary for palatial production, though these are largely ephemeral, traceable only with certain types of well-preserved materials suitable for provenience study. We can, however, know something about the nature of these networks, based on what happens after the collapse of the palaces at the end of LH IIIB2. Contrary to conventional notions of decline in long-distance relationships after the collapse of the palaces, long-distance interactions are largely maintained, especially in the Euboean Gulf (Crielaard 2006; Parkinson 2010; Kramer-Hajos 2016). The aspects of palatial production that relied on imported goods would have been mediated by regional connections. This should be expected, given the inland location of nearly all the palatial centers. But it also gave the coastal settlements through which imports had to pass a stake in these networks, which they exploited following the LH IIIB destructions. So, while consumption and certain aspects of production would have redrawn the map of long-distance networks to focus on the palaces in the Palatial period, these polities would also have depended on their regional networks for raw material procurement. The distributed nature of craft production explains the continuation of some long-distance contacts following the collapse of the palaces, in contrast to the coincident loss of writing and other trappings of centralized palatial authority.

\section{THE BIGGER PICTURE AT THE END OF THE BRONZE AGE}

The Late Bronze Age eastern Mediterranean was home to a variety of states, kingdoms, and empires, joined together by interactive systems of trade and diplomacy. The territorial empires of Egypt and Hatti were the most powerful of these, though 

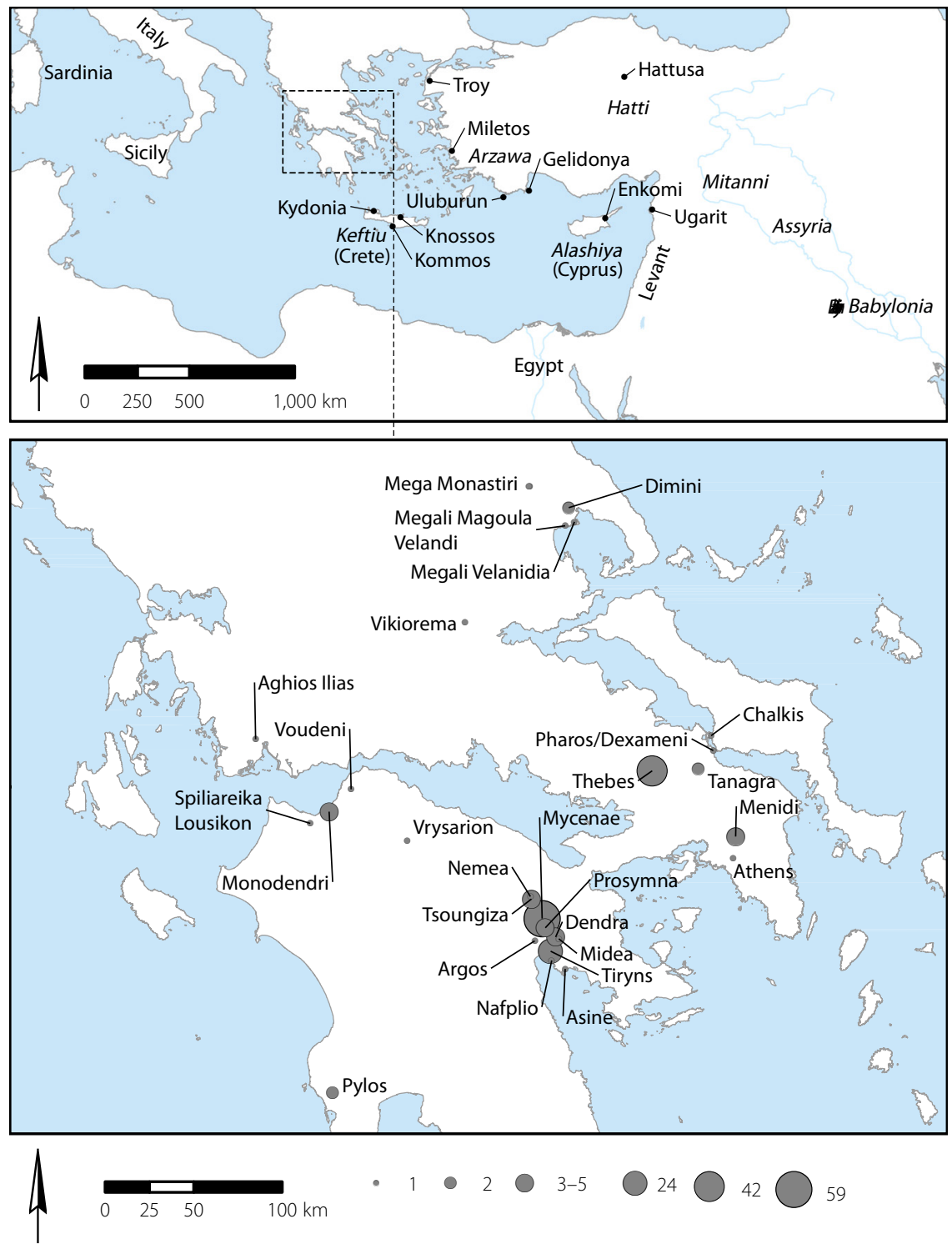

MAP 13. Sites and kingdoms of the Late Bronze Age eastern Mediterranean and Near East (top) and Imports to Greece of LH IIIB date (bottom) (import data from Murray 2017, 83-84, table 2.1).

major polities are also known from Cyprus (Alashiya), Anatolia (Arzawa, Troy/ Wilusa), Mesopotamia (Babylon, Assyria, Mitanni), the Levant (Ugarit), and Crete (Keftiu) (map 13). Mycenaean Greeks appear in Hittite records as Ahiyyawa, 
and they are mentioned in Egyptian texts as well. The presence of Aegean material culture throughout the eastern Mediterranean shows involvement in wider trade networks throughout the Bronze Age, as do imports, mainly in the form of luxury items or "exotica" at Aegean sites.

The archaeological and documentary records of Egypt, Hatti, and Mesopotamia show that these are territorial states with complex, hierarchical modes of sociopolitical organization. Political and religious institutions were well established, long-standing, and designed to enforce state control over multitiered systems of settlement. Less is known about political organizations elsewhere in Anatolia, in Cyprus, and in Crete, though these polities seem to have been smaller in scaleboth physically and in terms of estimated territorial control or influence. Ugarit fits more of a city-state model and was an important precursor to the commercially oriented city-states known in the Levant in later times. A rich documentary record, primarily written in Akkadian cuneiform (the lingua franca of the eastern Mediterranean Late Bronze Age), highlights diplomatic and trade relationships as central modes of interpolity relationships. Rulers addressed each other as "my brother" or "great king" while negotiating trade agreements concerning copper, gold, silver, and timber; when exchanging gifts in the form of luxury items; and when negotiating alliances and diplomatic marriages. Territorial conflicts and war also feature in the documentary record, including extensive self-aggrandizement on the part of rulers and two different versions of who won the famous Battle of Kadesh (the Hittites and Egyptians each claim they did). The insights into elite life, a "globalizing" early economy, and multipolity statecraft are truly remarkable.

Two issues have long dominated discussion of the eastern Mediterranean Bronze Age: diplomacy and trade between "great kingdoms" and the "collapse" of civilizations around the year 1200 BCE (see, e.g., Bryce 2003; Cline 2014; Knapp and Manning 2016; Middleton 2017a; Murray 2017). These themes are often presented in a way that equates what was going on in Greece at the end of the Bronze Age with what was happening elsewhere in the eastern Mediterranean. Just as power relationships existed within complex societies, inequalities existed between them. The Mycenaean palatial states were not of the same order as their Near Eastern contemporaries, something that becomes clear from a comparative analysis of texts that indicate relationships between polities and scale of complexity as measured through administration, territory, and physical vestiges of stately authority. In the same way that all parts of the Mycenaean world were not palatial, not all parts of the eastern Mediterranean interaction zone were "great kingdoms." Here I highlight this disparity to reevaluate the place of early Greece in Late Bronze Age trade and geopolitics. I then turn to the ample evidence for Mycenaean involvement in the western Mediterranean, which is often left out of such discussions and may prove a useful case for comparison, especially in the long term. I leave the subject of collapse for the following chapter. 


\section{Commodities Trade in the Eastern Mediterranean}

Archaeological evidence of materials on the move and textual correspondence concerning individuals and polities are our two main proxies for long-distance interaction in the Bronze Age eastern Mediterranean. Trade has played an important role in our understanding of Mycenaean society, as archaeological evidence of imported materials and finished products is paired with textual evidence for diplomatic relationships, resulting in a range of models (see, e.g., Renfrew 1975; Cline 1994; Knapp and Cherry 1994; Feldman 2006). Reciprocal gift giving between heads of state has received special attention as a way of explaining the relatively small amount of luxury "exotica" found in palatial contexts (Cline 1995). Such practices can only represent part of the picture, however, which also would have included subelite trading networks, independent merchants, raw material exchanges, tramping, and more, much of which is difficult to parse from the archaeological or textual record. Nevertheless, it is worth revisiting the archaeological evidence of long-distance trade and the textual evidence of diplomatic relationships in light of the local and regional political and production networks discussed above.

Data on all "international" imports to Mycenaean Greece were compiled long ago by Cline (1994), and this catalog has been put to a variety of uses since (see, e.g., Cline 2007, 2010a; Parkinson 2010; Burns 2010; Galaty 2018). Murray (2017) has updated and significantly expanded this dataset through a thorough reinvestigation of import records, taking into account excavations over the last 20 years, starting with the LH IIIB period (see map 13), and including LH IIIC, Protogeometric, and Geometric periods as well (discussed in subsequent chapters).

Cline's data has the advantage of including earlier Mycenaean periods (Cline 1994, 16-19, tables 6 and 7). The data show a clear shift in the amount of imports from the LH IIIA to LH IIIB periods, with the Cretan sites Knossos and Kommos having distinctly more imports than the mainland sites of Mycenae, Tiryns, and Thebes in periods before LH IIIB, followed by the opposite pattern in LH IIIB (Cline 1994, 89-90). This pattern could be the result of a Mycenaean takeover at Knossos (Cline 1997), and it at least seems to represent a reorientation of eastern Mediterranean trade networks toward the newly established Mycenaean palaces of the mainland and away from Crete. Significantly, Kommos, in southeastern Crete, seems to stay well-connected, suggesting that certain hubs remained important for long-distance trade, despite changes in political structures; this appears to be a long-term trend at Kommos, which has demonstrable Phoenician connections in the Early Iron Age as well (Shaw 1989, 2000; Callaghan et al. 2000).

For central Greece, Thebes has by far the most imports in the Palatial period. Cline $(2007,191)$ has pointed out that most of the 38 orientalia from Thebes come from a single context-a hoard of cylinder seals from the so-called "Treasury Room" (Porada 1981) - suggesting that they should be taken as anomalous. This is possible but, again, we must keep in mind that only small, fragmentary sections 
of Thebes have been excavated. If anything, we should expect much more such material from Thebes, given the wealth of imports found in only a few excavated contexts (Burns 2010, 135-39). The chronological scope and origins of excavated material from Thebes are also telling. There is no significant quantity of imports until LH IIIB, which is coincident with the expansion of the palace, the appearance of Linear B, massive expansion in the fortification of the site, and dramatic increase in settlement remains on a local and regional scale. The provenances of these imports are also significant, though they require thoughtful consideration. While their origins include different parts of the ancient Near East, including Egypt, Syro-Palestine, Cyprus, and Mesopotamia (Porada 1981, 46; Kopanias 2008), this does not mean that they came to Thebes directly from these original locations. Moreover, many of these seem to have been reworked in Theban workshops into more traditional Mycenaean motifs, such as the figure of eight shield, suggesting it was the exotic material rather than the particular message associated with foreign administration that bore symbolic significance (Burns 2010, 138; 2016).

The quantities and locations of import evidence are significant. In central Greece, they are limited to relatively few well-excavated sites, and they skew toward ones with Palatial remains. Overall, however, imports are much more abundant in the Argolid, though this may also have something to do with the history of research (see map 13).

There is extensive evidence that Mycenaeans exported pottery to various parts of the Mediterranean, especially to Cyprus and the Levantine coast (van Wijngaarden 2002; Jones et al. 2014; Murray 2017, 192-99). This wide distribution, which also includes western Anatolia and Italy, suggests that Mycenaeans were involved in trade networks during the Palatial period that included several other eastern Mediterranean states (Sauvage 2012). Trade is apparent through the broader circulation of pottery and the transfer of styles through different parts of the Mycenaean world, not least transport amphoras and inscribed stirrup jars (Haskell et al. 2011; Rutter 2014b; Demesticha and Knapp 2016; Knapp and Demisticha 2017). While this form of exchange appears to reach its height in the Palatial period, we should note that it also predates that period and lasts beyond it (van Wijngaarden 2016; Murray 2017, 194). This form of exchange cannot therefore be considered an exclusively palatial phenomenon; rather, it should be considered as one that was magnified by the palaces-probably through the increased demand they created for status-granting exotica and the desire to trade their own pottery, oil, textiles, and other products. ${ }^{27}$

The various ways in which we might view trade in the eastern Mediterranean Bronze Age should not be seen as mutually exclusive: centralized control, localized control, freelance trade, and gift exchange likely all operated simultaneously.

27. For an argument supporting palace-centric exchange of pottery between the Argolid and various Near Eastern states, see Jung 2015. 
Such practices should be seen as co-constitutive types of long-distance interaction rather than as options from which we must select. For example, centralized control is dependent on localized control since, in the example of a Mycenaean palace, it is unlikely that a wanax made all trade-based decisions independently. Gift exchange can be seen as either an incidental, specific phenomenon or the terms in which the trade of particular goods are cast (Cline 1995). And the cargoes of shipwrecks, such as Cape Gelidonya (Bass 1967) and Uluburun (Bachhuber 2006; Pulak 2008), contained materials from multiple locations, which have been used to argue for a variety of the above-mentioned modes of exchange (see, e.g., Shelmerdine 2013, 451).

Although trade was probably mediated through both regional networks and freelance traders, consumption of exotic materials was certainly in the domain of the elite and was carefully controlled to project exclusivity and access (Burns 2010; Kramer-Hajos 2016). Tensions caused by this exclusivity, like conscripted labor and centralized elite consumption, among other things, may have contributed to the ultimate collapse and rejection of the Mycenaean palace system.

\section{The Documentary Record and Geopolitics}

While Linear B documents tell us nothing directly about interpolity relationships, toponymics and onomastics have slightly more to say. They suggest that a certain amount of multiculturalism was present in Mycenaean society in the form of resident foreigners as workers, settlers, or slaves with non-Greek names (Nikoloudis 2008a). The nature of interactions between Mycenaeans and "others" is far from clear, although the occurrence of them is certain. In central Greece the Thebes tablets indicate individuals with names related to Troy, Miletos, Sminthos in Anatolia, and Sparta. These names do not indicate that a particular individual is necessarily from this place, though that could be the case. They probably do signal an awareness of cultural geography beyond a particular community or region, which was likely highlighted at places like palaces that attracted greater amounts of longdistance exchange.

Hittite texts provide the most extensive and debated body of evidence for contact between the Aegean world and other polities. They make apparent reference to the Mycenaeans of mainland Greece with the term Ahhiyawa, which appears in some 29 documents from the Hittite capital of Hattusa. It is argued that this term is a form of "Achaia" and has led to much debate over whether (1) this linguistic connection is correct and (2) what type of entity it refers to (Güterbock 1983; Latacz 2004; Beckman, Bryce, and Cline 2011). This issue is generally referred to as the "Ahhiyawa question" or the "Ahhiyawa problem" (Fischer 2010) Most scholars now accept the identification of Ahhiyawa with some part of the Mycenaean world (Beckman, Bryce, and Cline 2011, 6). Whether this refers to a specific polity within the Mycenaean world or to the Mycenaean world collectively remains less certain (Bryce 2018). A relatively recent trend has been to suggest that these documents 
refer to a single polity ruled by a "great king" on par with others of the eastern Mediterranean (Latacz 2004; Kelder 2010; Eder and Jung 2015).

The "Tawagalawa Letter" (AhT 4) is from a king of Hatti to a king of Ahhiyawa and refers to him as "brother" and "Great King," a title used only for kings of Hatti, Egypt, Mttanni, Assyria, Babylon, and-in this one instance-Ahhiyawa. ${ }^{28}$ Other comparisons between these polities and the Mycenaean world, however, fall short, both materially and in the documentary record. The corpus of Hittite texts contains around 1,00o total documents, of which only 29 make reference to Ahhiyawa. Egypt, Mitanni, Aleppo, Arzawa all appear much more frequently. The ways in which Ahhiyawa is referred to are also significant. Besides the document addressing an Ahhiyawan king as "Great King," there is one further document that gives this title (AhT 2), but the designation there appears to have been erased by the scribe, suggesting that it was a mistake (Beckman 1996, 101). One interpretation of this erasure is that the title was one that once applied but was no longer valid; it may also have been a simple mistake at the end of the list.

There is very little evidence of Mycenaean participation in anything that could be called statecraft. Only one letter from the Hittite corpus is meant to be from a king of Ahhiyawa to a Hittite king. It is written in Hittite, probably by an emissary or translator. This letter concerns a land dispute over some islands, presumably near the Anatolian coast, and it mentions a diplomatic marriage. Other letters concern trade restrictions to Assyria (AhT 2), Millawanda, which is typically associated with Miletos, and various conflicts or disputes either between Ahhiyawa and the Hittite empire or its allies. These include references to several places in the eastern Aegean, including-provocatively-Wilusa, which has been equated with Ilios/Troy. No texts in the Akkadian cuneiform lingua franca of the LBA eastern Mediterranean have been found in Mycenaean palatial contexts.

The maximalist interpretation of the Ahhiyawa texts is that they signal the presence of a single Mycenaean state that was a known participant in eastern Mediterranean relations, a state that occasionally caused problems for the Hittites by harrying their allies along the east Aegean coast. Most proponents of a single, unified Mycenaean polity would place the capital at Mycenae itself, based on the evidence for its long-distance connections (Kelder 2010, 93-99; Eder and Jung 2015). Others have suggested that such a capital would be at Thebes (Sergent 1994, 1997, 1999; Aravantinos, Godart, and Sacconi 2001; Latacz 2004), or that Ahhiyawa refers to Miletos specifically or the southeast Aegean/west Anatolian interface more generally (Mountjoy 1998, 2015; Niemeier 1999, 2005). An immediate problem with all of these arguments, however, is that the Linear B evidence contradicts any kind of argument for political integration across the Mycenaean world, since it refers only to individual regional systems centered on a particular palace.

28. Here I use the numbering system found in Beckman, Bryce, and Cline (2011) rather than the official tablet numbers of the Catalogue des Textes Hittites (CHT). For a comprehensive discussion of Hittite diplomatic texts, see also Beckman 1996. 
Moreover, the very archaeological evidence often cited as a sign of unity (similar architectural layouts in palaces, administrative systems, pottery styles) is in fact quite varied from region to region, not least because much of the area grouped together as the Mycenaean world cannot be convincingly characterized as palatial.

As an alternative, Ahhiyawa could very well be a cultural designation, in much the same way that we think of the term "Mycenaean" as a cultural rather than a political designation (see also Bryce 2018). When references are made to the king of Ahhiyawa there should be no problem accepting this as a reference to $a$ kingdom within the Mycenaean cultural sphere, even if it is a reference to a specific kingdom. Nor, as Beckman, Bryce, and Cline (2011) have pointed out, is there a problem with coalitions forming for various purposes, coalitions that the Hittites may have recorded as a singular entity. Most of what we know from later Greek textual sources, in fact, tells us that this practice was much more common than, say, a unified territorial state was. Homer, of course, refers to numerous leaders of the Achaians as kings, and Archaic and Classical political history is in many ways a history of alliances. Similar practices are seen in other early complex polities as well, such as the Classic Maya, who are characterized by shifting political histories of independence, conflict, alliances, and coalitions (Martin and Grube 2008; Garrison 2018; Ek 2020).

The Aegean also appears in documents from Egypt, the other great power of the Late Bronze Age, though evidence is limited. The most famous set of diplomatic texts from Egypt, the Amarna letters, do not discuss the Mycenaean world at all (although earlier Egyptian texts do seem to mention Crete as Keftiu). However, the more or less contemporary statue base of Amenhotep III, found at his funerary temple at Kom el-Hatan, contains an "Aegean List" in which several place names are given that can be tied to Crete and mainland Greece (Edel 1966; Cline and Stannish 2011), under the headings of Keftiu ( $k f t i w)$ and "Tanaya" (tny, also read as Danaia, land of the Danaans). The order of the list is significant, as it seems to describe a geographical circuit beginning with Amnisos, Phaistos, Kydonia, Mycenae, an unidentified dqis (possibly Thebes), Messenia (Pylos?), Nafplio, Kythera, Eleia, Knossos, Amnisos (for a second time), and Lyktos (possibly Siteia) (Cline and Stannish 2011, 7-9). The list goes from Crete to the mainland and back to Crete, apparently describing an itinerary. These place names are written on crenelated ovals carved over bound captives-a standard practice in Egyptian depictions of foreigners. Egyptian-Mycenaean interaction is also represented in several faience plaques from Mycenae, bearing cartouches of Amenhotep III and Queen Tiye, and Knossos, Kydonia, and other sites have also revealed scarabs and seals (Cline and Stannish 2011, 10).

Much is made of Late Bronze Age trading systems and kingly gift exchange as a major part of both economic and diplomatic relations. Based on the Hittite and Egyptian texts described above, the Mycenaeans are seen to be participants in such a set of interactions. In only one, or perhaps two, of the Hittite documents there is 
reference to a "Great King" of Ahhiyawa. In the Egyptian text the reference to the Aegean is embedded in the iconography of subordination. The only other direct mention of the Aegean is in a single text from Ugarit-which is a letter from the king of Hatti (RS 94.2530). This letter indicates Ahhiyawan and Ugaritic participation in the trade of copper ingots.

From this fragmentary textual record, two observations can be drawn out. First, there is no definite evidence for a large territorial state-the size or nature of a Mycenaean kingdom is never described. More importantly, the Linear B evidence, where it exists, does not support this model, and the archaeological landscape, as described at length above, suggests an even larger degree of fragmentation, not unification. Second, there is no clear evidence for a Mycenaean "great kingdom" on par with other polities with that title. Assuming Ahhiyawa refers to Mycenaean Greece, it is only referred to by the Hittites; this would suggest that Hatti was the main broker of state-like dealings with a Mycenaean polity. The absence of other diplomatic correspondence is conspicuous, since other states, rulers, and institutions from all over the Near East are discussed at length. When considered together with the evidence of regional political organizations, we can say (1) that Mycenaean polities were comparatively small-scale in their territorial extent and (2) that their activities abroad were mostly focused on the eastern Aegean and western Anatolia.

Mycenaean palatial states were not proper peers of the older and much more territorially expansive states of Babylonia, Assyria, Egypt, Hatti, or Ugarit. This is evident in comparisons of territory, palatial plans, and overall urban character (see also Whitelaw 2004, 2017, 2018). However, Mycenaean polities were well aware of these more complex entities, interacted with them, and understood something of how they worked. Indeed, certain Mycenean centers even attempted to imitate other polities in their own political organization. The imposition of state-like modes of social organization in the Mycenaean world, however, happened in limited areas and for a relatively brief span of time, and it was ultimately not very successful.

\section{Looking West}

One of the most interesting features of the Mediterranean in the late second millennium BCE is the way in which the (mostly) small-scale societies of the western and central part of the basin were brought increasingly into contact with the more complex political formations of the east (see, e.g., Broodbank 2013, 431-44). Our evidence for these interactions is entirely archaeological and of a different character from that seen in the eastern Mediterranean. It comes mostly in the forms of Mycenaean and "Mycenaeanizing" pottery in southern Italy, with more modest quantities found in Sardinia, Sicily, and northern Italy (van Wijngaarden 2002, 2016; Eder and Jung 2005; Vianello 2005; Blake 2008; Cazzella and Recchia 2009; Jones et al. 2014; Iacono 2015, 2016a, 2016b). Iacono (2015) points out that the smaller communities in which cross-cultural encounters were happening in 
southern Italy makes them especially significant. That is, they would have been accessible to a larger amount of the population of a site, rather than restricted to an elite or merchant class. This seems borne out in the material record as well, as fine wares make up the vast majority of assemblages found at Levantine, Cypriot, and Egyptian sites, while Italian sites have more diverse assemblages with a range of types (Murray 2017, 196). It therefore seems to be the case that Mycenaeans were coming to southern Italy not just as incidental visitors and traders but as migrants with an interest in establishing a continuous presence.

Iacono (2016a) has made a compelling argument for the transfer of technological traits between "hegemonic" (Mycenaean) and "nonhegemonic" cultures (south Italian). We might also see this as a more equitable arrangement than we see in relations between the Aegean and the states of the Near East. Some Aegean societies were interested in adopting certain stately trappings of their Near Eastern neighbors and trading partners in the Late Bronze Age. By contrast, the societies of the central Mediterranean seem to have been more interested in material and technological practices, which had social value in their own right. What is viewed as the valuable contribution of one society-that is, cultural traits worth adopting-depends on the mode of encounter and the value systems of both social groups. It may well be that in this case the Aegean continued to play its longstanding role of geographical and cultural middleman, situated as it was between the stately societies of the eastern Mediterranean and the nonstate societies of the center and west, while Mycenaean Greece itself was comprised of polities occupying a range of sociopolitical formations. The Achaian connection to Italy is compelling in this sense. It is at a geographical crossroads to Italy and the Adriatic and it is also the likely source of much of the Mycenaean pottery found there (Papadopoulos 2001, 2003; Arena 2015; Jung, Mommsen, and Picciarelli 2015). This suggests that like may have been attracted to like in terms of trading relationships, with palatial sites directing the bulk of their attention toward the polities to which they aspired, while nonpalatial Mycenaean societies (e.g., in Achaia) looked elsewhere. Indeed, it may be the lesser-known orientations (westward) that were more meaningful in the long term, or at least more lasting than the short-lived palatial engagements with the east.

\section{CONCLUSIONS: POLITY AND VARIETY IN THE MYCENAEAN WORLD}

The political landscapes and interactions of Mycenaean central Greece involved a variety of regionally (and locally) distinct patterns of settlement and modes of social organization. This sheds new light on the particular polities of central Greece discussed here, on the wider Mycenaean world, and on the eastern Mediterranean in the Late Bronze Age. While settlement networks and landscape archaeology offer insights concerning particular relationships between places 
within central Greece, larger patterns of interaction can also elucidate some of the dynamic changes seen during the Palatial period. These are especially apparent in the regions where palaces existed, but these shifts had less exaggerated effects (and consequences) in areas devoid of palatial authority.

Mycenaean palaces came to thrive through the implementation of new sets of integrative and centralizing practices. After steady growth in sociopolitical complexity during the formative Mycenaean period, the palaces emerged very quickly as elites took advantage of long-distance trade relationships and new administrative technologies to consolidate and expand authority, reifying it both architecturally and practically through a new administrative system, partly borrowed from Crete. This rapid, deliberate growth in connections in effect kick-started a scalefree network, where communities attached preferentially to the most highly connected places-the palaces. This preferential attachment would have been based partly on the integrative actions of palatial authorities and partly on the restructuring of social relations that came with this new political form. But palatial influence did have limits.

Increased connectedness across the Mycenaean world as a whole, especially between palatial centers participating in peer-polity networks, also helps to explain the relative homogeneity that permeates much of Mycenaean material culture beginning slowly in LH IIIA and reaching an apex in LH IIIB. The links between palatial centers both within and outside the Aegean were felt regionally and locally as well, and were manifest in such things as monumental architecture, ceramic styles, bodily adornment, and burial forms (Mountjoy 1990, 245; Cavanagh and Mee 1998; Crowley 2008, 266; Nosch and Laffineur 2012; see also Kramer-Hajos 2016). So, while a great variety of political organization existed across the Mycenaean world, people-especially elites-were still participating in social networks that linked communities together. This is to be expected across a culture area with several independent political centers that operate at different scales in a variety of ways.

The Linear B tablets make it clear that the regional systems over which the palaces presided centralized several aspects of agricultural and craft production. This system allowed for the consolidation and, to some extent, the redistribution of such products, especially through state-sponsored feasts (Wright 2004a; Small 2019). These types of consolidation and consumption were opportunities to centralize social power and state authority through routinized practice. Such centralization, however, was built on weak institutions, was rapidly introduced, and left the whole system fairly vulnerable to collapse. This vulnerability explains the rapid disappearance of Linear B and the disappearance of palatial systems following the destruction of the palaces in LH IIIB2. It also suggests that a collapse of overseas trade networks was not a prime mover in bringing about the end of the palaces, though no doubt it could have been a contributing factor. I demonstrate in the next chapter that these long-distance connections do not in fact break down 
entirely, and that some of the material and settlement changes seen in LH IIIC are the direct result of efforts to reengage or maintain them. Moreover, the collapse of centralized systems at the end of the Palatial period resulted in even greater regional diversity as new centers emerged in new locations, with more focus on the sea and on practices of production and consumption that were less centralized.

The picture above follows the general consensus that Mycenaean palaces were independent, centralized regional polities. I depart from canonical views in suggesting that these polities were few, limited in territorial remit, and should be seen as historical anomalies that never had enough time to establish stable institutions (see also Sherratt 2001). Palaces certainly demand and deserve attention, with their monumental architecture, wealthy burials, and complex administration. But we must also keep in mind that these represent massive social inequalities that disrupted long-standing modes of social and political life. We should also remember that mainland palatial societies did not last very long. Whatever the circumstances of their demise - interpolity conflict, natural disaster, or peasant revolts-the palaces ended with a rejection of this system by those participating in it. From this perspective, we should not think that being outside the palatial world represents some kind of failure-quite the opposite, as we can see in the regions that come to thrive in the period that follows (chapter 4 ). Fragmentation and instability were the norm, and the palatial system imposed from above was ultimately rejected from below. Concerning views on the opposite end of the spectrum (e.g., Kelder 2010; Eder and Jung 2015), the evidence for centralized organization across the Mycenaean world seems to me entirely circumstantial. This desire to conceive of a Mycenaean empire on par with Hatti and Egypt is not well supported by comparative evidence, and it is better replaced with a model that allows for a range of sociopolitical complexity and organization both within early Greece and across the Mediterranean.

The Mycenaean palaces were peripheral participants in wider interaction spheres of the eastern Mediterranean, and nonpalatial entities likely participated as well in the capacity of raiders or traders, as they had in the Early Mycenaean period and would in the Postpalatial period (Hitchcock and Maeir 2016). Moreover, in comparison to other stately modes of political organization in the contemporary Near East, the Mycenaean palaces seem rather weak. For cases of comparison, for the palaces and especially for the other polities of Bronze Age Greece, we should turn away from models of pristine state formation, on the one hand, and the organization of contemporary polities in the Ancient Near East, on the other, not least because some of these other polities at this point were full-fledged empires. Rather, Mycenaean palaces developed as a type of secondary state on the Greek mainland, one that was heavily influenced by contacts with neighbors and trading partners, especially in Minoan Crete. As such, the palaces developed relatively quickly and without necessarily adapting other social structures to develop strong institutions and engender stability. The Mycenaean palaces, therefore, were never particularly 
strong states, and indeed the implementation of palatial systems was very much piecemeal across the Mycenaean world. From this perspective, it should be no surprise that these political formations collapsed. Nevertheless, the arrival and collapse of this new form of polity had dramatic effects on local and regional systems of settlement and subsistence. In nonpalatial areas, however, life went on, in dialogue with palatial zones, though well outside the limits of any palatial hegemony. 